\title{
The Rockall Trough, Northeast Atlantic: the Cradle of Deep-sea Biological Oceanography that is Now Being Subjected to Unsustainable Fishing Activity
}

\author{
J. D. M. Gordon \\ Scottish Association for Marine Science, Dunstaffnage Marine Laboratory, \\ Oban, PA37 1QA, United Kingdom
}

\begin{abstract}
The Rockall Trough or Channel is a clearly delimited deep-water area lying to the west of the British Isles. The eastern and western boundaries are formed by the continental margin and the Rockall Plateau, respectively. To the north it is separated from the colder Norwegian Sea by a ridge at about $500 \mathrm{~m}$ depth. To the south the depth steadily increases to abyssal depths. In the $1860 \mathrm{~s}$ and 1870 s some of the earliest descriptions of deep-water fishes were from this area. This review documents the late $19^{\text {th }}$ and early $20^{\text {th }}$ century investigations of the fish populations. The U.K. and Germany carried out deep-water exploratory fishing surveys in the 1970s and 1980s and detailed biological studies by the Scottish Association for Marine Science began in 1975. These, and other more recent studies, have added considerably to our knowledge of biology and ecology of the deep-water fishes. General accounts are given of the key features of the target and non-target species and families.
\end{abstract}

Although some deep-water fishing began in the 1970s the rapid increase in commercial exploitation did not begin until 1989. As a result, there is information on the fish populations and their biology that pre-date the fishery. Since then, several countries have carried out research surveys in the area and there has been some monitoring of landings and discards.

Concerns about the vulnerability of the fish stocks have been documented since 1993 and International Council for the Exploration of the Sea (ICES) has assessed the status of the stocks since 1998. They are currently considered to be outside safe biological limits. The most recent ICES advice is for a $50 \%$ reduction in fishing effort for the main target species. Despite ICES advice, the fishery remains unregulated. There are also concerns about the impact of the fishery, especially bottom trawling, on what is generally considered to be a fragile ecosystem.

This paper revisits the documented concerns about the vulnerability of the fish stocks and their habitat and describes the transition from what is probably one of the best-studied deep-water ecosystems to an area that is being subjected to unsustainable exploitation of its fish populations.

Keywords: deep-water fishery, ecosystem, fishing impacts, Rockall Trough, sustainability

\section{Introduction}

The Rockall Trough and the adjacent FaroeShetland Channel has aptly been described as the cradle of deep-sea biology by Gage (2001). The deepwater fish fauna was fairly accurately described before the end of the first decade of the $20^{\text {th }}$ century. Occasional fishery-related surveys were carried out in the intervening years, but the significant period of scientific investigation began in the 1970s. The Scottish Association for Marine Science (SAMS) multi-disciplinary approach to the study of the Rockall Trough, programs such as Land Ocean Interaction
Study (LOIS) and deep ocean benthic boundary (BENBO), and the oil-related impact assessments have provided a wealth of knowledge on the physical and biological oceanography of the area. The wide-ranging fisheries surveys carried out by the U.K. and Germany in the 1970s and 1980s provide a unique insight into the pre-fishery state of the stocks. Subsequent and ongoing surveys from the early-1990s by Ireland and the U.K. are and will be of great value in helping to evaluate the impact of the current fishery. The detailed site-specific studies by SAMS in the Rockall Trough and SAMS/IOS at two transects in the Porcupine Seabight have not only defined the fish assemblages, 
but also provided material for studies of biological parameters with particular emphasis on growth and reproduction where seasonality of sampling is important. The recent French surveys at the same specific site in the Rockall Trough have added substantial new post-fishery data from this well sampled area. It is frequently stated that not enough is known about the biology of deep-water species but, as this review indicates, the amount of published information on both target and non-target species is rapidly increasing.

The development of the commercial deep-water fishery has been well documented since its inception. The evaluation of CPUE data, the market sampling of landings and the studies on discarding, which were supported as part of the European Commission Deepfisheries Project, added greatly to our knowledge, but it is a concern that such work has diminished following the completion of the project. The timeseries of CPUE, although short, have enabled the stocks to be assessed and the advice from International Council for the Exploration of the Sea (ICES) is that all the exploited fish in the Rockall Trough are being fished outside safe biological limits. Given the longevity of the fish, the high age at first maturity and the high mortality of immature fish, it is probable that the true effect of the fishery throughout the 1990s has not yet become evident.

This review describes the physical features of the Rockall Trough and documents some of the earliest $19^{\text {th }}$ century studies on deep-water biological oceanography that were carried out in the area. The $20^{\text {th }}$ century investigations of the fish populations are described and related to other physical and biological studies. An account is given of the biology and ecology of the deep-water target and non-target fish species. The development of the fisheries, their assessment and their status are briefly reviewed. The impacts of fishing on the fragile deep-water ecosystem, although poorly understood, are discussed. ICES had provided management advice for the main target species to the European Commission and the North-East Atlantic Fisheries Commission. The processes that have led to the formulation of the advice are described but, as yet, none of the management proposals have been adopted.

\section{The Rockall Trough}

Rockall is a granite rock with a base of about 25 $\mathrm{m}$ in diameter and a height of about $19 \mathrm{~m}$, which lies about 200 miles west of the Hebrides (Anon., 1974).
It is not known when it was first discovered, but the first authenticated landing is stated as occurring in 1911 (Anon., 1974). Blacker (1982) comments that fishing had probably been taking place on the surrounding bank for more than two centuries. Possession of the rock was claimed by the U.K. in 1955 and in 1972 it was incorporated into the U.K. The original objective was military, but later its ownership had economic significance when a 200mile exclusive fishery zone was declared around the rock in the 1976. Greenpeace occupied the rock in 1997 as part of their campaign against oil exploration in deep waters and later that year the U.K., while continuing to claim ownership of the rock, renounced its claim to a 200-mile fishery zone. The consequences of this for deep-water fisheries will be described below. The development of the shallower-water fisheries on the Rockall Bank has been described by Blacker (1982).

Maury's first bathymetric chart of the North Atlantic of 1854 (reproduced in Murray and Hjort, 1912) shows the first indication that an area of deep water, subsequently to be known as the Rockall Trough or Channel, lay between the Rockall Bank and the Hebrides. Several expeditions surveyed the deep-water areas to the west of Scotland and Ireland and around the Faroe Islands with the result that the map compiled by John Murray in 1911 clearly shows the Rockall Trough very much in the form that we know it today (Murray and Hjort, 1912). Figure 1 shows the modern bathymetry of the Rockall Trough. At a depth of about $500 \mathrm{~m}$, the Wyville-Thomson Ridge forms the northern boundary of the Rockall Trough. This is a major faunal barrier and there is little similarity between the deepwater fish assemblages on either side of the ridge. To the west and northwest, the Rockall Plateau and a chain of northern banks separate the Rockall Trough from the Icelandic basin. To the south the Rockall Trough gradually increases in depth and eventually merges with the abyssal plain. The Porcupine Bank, which lies to the west of Ireland, has a steep slope where it forms an eastern boundary of the Rockall Trough. However, lying to the south of the Bank is an area with more gentle slopes, the Porcupine Seabight, which is sometimes considered as a separate entity, but for the purposes of this review it is considered as part of the Rockall Trough.

The underlying geology of the Rockall Trough has been described by Scrutton (1986) and the resulting structure of the continental margin by Jones et al., (1986). Most of the area is covered with sediments whose deposition has been modified by volcanic activity, bottom currents and glacial processes. 


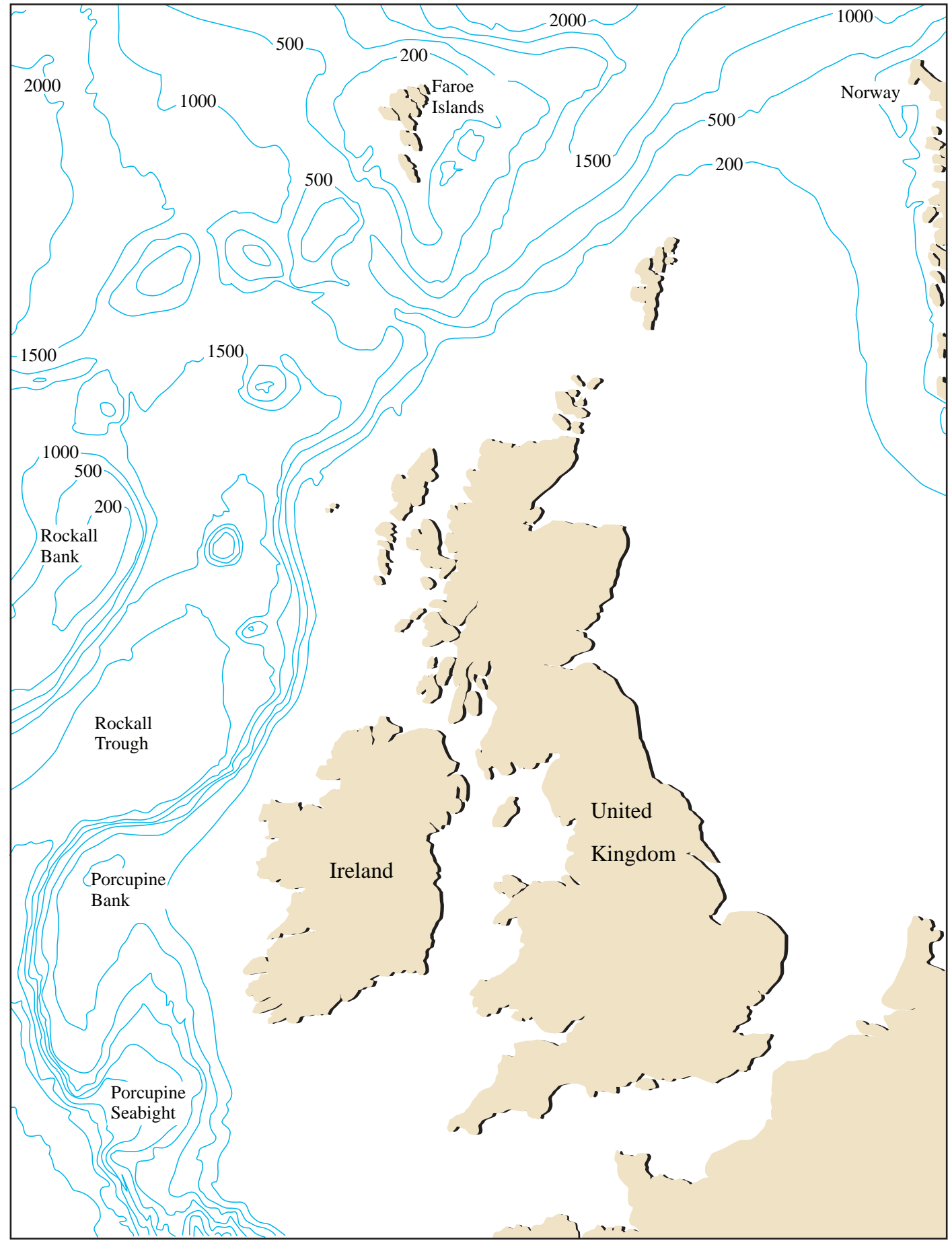

Fig. 1. The Rockall Trough, Northeast Atlantic.

\section{$19^{\text {th }}$ Century Explorations in Deep-water Biological Oceanography}

The deep waters to the west of the British Isles have played an important role in the field of biological oceanography. In 1844, Edward Forbes published his work on the depth distribution of animal life and proposed his Azoic Theory, which suggested that there was no animal life below about 300 fathoms $(550 \mathrm{~m})$ (Forbes, 1844). Although, as described by Currie (1986), there were occasional reports of life in waters deeper than this, it was not until the cruises of the 
vessels Lightning and Porcupine to the west of the British Isles in 1868 and 1869 that the theory was finally disproved (Thomson 1873). Interesting accounts of these and other early oceanographic vessels and their work are to be found in Rice (1986). The Lightning, a 126 foot wooden paddle gun-vessel, was loaned by the Navy to Wyville Thomson and Carpenter to investigate the deep waters to the west and the north of the Hebrides. The Lightning sailed from Oban on 8 August 1868 and after many problems, not least the poor weather, succeeded in dredging and recovering living animals from depths of over $900 \mathrm{~m}$ to the southeast of the Faroe Islands. Later in the cruise, another dredge haul at a similar depth, but further to the south, yielded a much richer catch. The bottom temperature at the first two stations was close to zero, while at the latter it was $6.4^{\circ} \mathrm{C}$. The vessel made one further deep haul in about $1190 \mathrm{~m}$ to the west of the Hebrides before returning to Oban.

In the following year HMS Porcupine, a 141-foot long, wooden paddle vessel, was loaned by the Navy and made three exploratory voyages. The first cruise covered a wide area to the west of Ireland, the Porcupine Bank, the Rockall Trough and the Rockall Bank. Dredging was carried out at depths down to $2700 \mathrm{~m}$. The second cruise searched for deeper water to the southwest of Ireland and recovered living material from a depth of $4289 \mathrm{~m}$. The third voyage returned to an area where the Lightning had discovered both warm and cold water, deep-water areas between Scotland and the Faroe Islands in the previous year. The Porcupine confirmed that substantial temperature changes occurred over relatively short distances. In his accounts of these cruises, Wyville Thomson (Thomson, 1873) notes that only a small number of fishes were caught by the dredges.

Following the round the world expedition of HMS Challenger between 1872 to 1876 , there was renewed interest in the deep waters to the west of the British Isles and, in particular, to the separation of cold and warm water between Scotland and the Faroe Islands. This resulted in the cruises of the Knight Errant and the Triton in 1880 and 1882, respectively. Soundings by the Knight Errant established the existence of an underwater ridge separating the warm and cold water, but the amount of biological sampling was limited. The Triton continued the work under the direction of John Murray and carried out hydrographic and biological surveys around the ridge. Preliminary lists of the fishes from the cold and warm water areas from these cruises and the earlier Lightning and Porcupine cruises have been given by Murray (1886). The underwater ridge separating the relatively warm Atlantic waters from the cold Norwegian Basin water was subsequently named the Wyville Thomson Ridge (Deacon, 1977). All 88 fishes caught by the Knight Errant and the Triton were included by Günther (1887) in his account of the fishes of the Challenger expedition. Ten new fish species were added to the British fauna from the Faroe/Shetland Channel.

In 1885 the Royal Irish Academy appointed a committee to investigate the marine fauna within the 100 -fathom $(185 \mathrm{~m}$ ) line off southwest Ireland (Went, 1971/72a). The first expedition using the Lord Bandon succeeded in dredging to $220 \mathrm{~m}$. In 1886 the Lord Bandon was again chartered for another expedition. After failures to dredge as deep as $2010 \mathrm{~m}$ a successful dredge was achieved at $594 \mathrm{~m}$. Trawling was also successful at $485 \mathrm{~m}$. In 1888 the Royal Irish Academy chartered the Flying Falcon (formerly the Lord Bandon) and carried out a trawling cruise at depths down to over $1800 \mathrm{~m}$. Relatively few deep-water fishes were collected during these surveys (Scharff, 1890).

The Royal Dublin Society promoted a survey of the fishing grounds to the west of Ireland and, with government aid, chartered the steam yacht Fingal in 1890 and the Harlequin in 1891 (Went 1971/72b). Although most of the survey work was on the shelf, some deep trawls were also carried out. An account of the fish catches is given by Holt (1892) and, subsequently, Holt and Calderwood (1895) described the rarer and deeper fishes collected.

Although the present paper is primarily concerned with fish, it should be noted that benthic invertebrates were also collected on the cruises of the Lightning, Porcupine, Knight Errant and Triton (Gage, 1986). Accounts of the early explorations of the pelagic fauna are to be found in the Reports on the Sea and Inland Fisheries of Ireland (Mauchline, 1986a).

\section{$20^{\text {th }}$ Century Exploration of Deep-water Fishes}

The Fisheries Branch of the Department of Agriculture and Technical Instruction for Ireland was established in 1899 and took over the role of the Royal Dublin Society. Investigations of the deep-water fishes continued under the direction of E. W. L. Holt using the Helga. There were in fact two vessels of that name (Rice, 1986). The first was a 145 -foot long steel twinscrew steam yacht, whose primary role was fisheries 
protection. For deep-water sampling she used a beam trawl not exceeding 35 feet and was limited by the amount of warp to fishing to a depth of about $900 \mathrm{~m}$ (Holt and Byrne, 1906). The second Helga was 155 feet long and was commissioned in 1908 (Green, 1908/ $09)$. Her principal role was also fishery protection, but she was also equipped for biological sampling with both trawl and hydrographic winches. From the account and station data given by Farran (1924), it appears that this Helga used the same trawl and was able to sample to depths of about $700 \mathrm{~m}$.

These investigations recorded the distribution of deep-water fishes to the west of Ireland and resulted in descriptions of many new species. Despite the relatively simple equipment available at that time, it is remarkable that these investigations described the fish fauna of the slope west of Ireland in considerable detail and the resulting series of publications are a valuable source of information (Farran, 1924; Holt and Byrne, 1906, 1908a,b, 1909, 1910a,b, 1911, 1913).

In 1910, the Norwegian research vessel Michael Sars carried out an exploratory survey of the Wyville Thomson Ridge and Murray and Hjort (1912) comment on the differences in the fish fauna on either side of the ridge determined from this and earlier cruises.

The Fisheries Laboratory of the U.K. Ministry of Agriculture Fisheries and Food (MAFF) carried out the next investigation of the deep waters. The steamtrawler Florence Brierley carried out 118 bottom trawls at depths ranging from about 160 to $1025 \mathrm{~m}$ (Hickling, 1928). The main objective was to survey the Merluccius merluccius (hake) populations, but notes were kept on all the other fish species caught. The areas sampled were the Faroe-Shetland Channel from the Wyville Thomson Ridge eastwards, the Scottish Atlantic Slope from the Wyville Thomson Ridge south to Tory Island and the Rockall Bank. A total of 61 species were recorded and their distribution between the three areas is discussed. There was considerable similarity between the deep-water catches of the Scottish slope and the Rockall Bank, but those from the cold deep water of the Faroe-Shetland Channel were markedly different. The quantity of fish from a standard tow in the Faroe-Shetland Channel was also much less than that at corresponding depths on the Scottish slope.

The MAFF carried out further exploratory surveys in 1960 and 1961 at several locations to the west of
Ireland and also at Rockall and George Bligh Banks. The main purpose was to search for new grounds for commercially viable fisheries and for this purpose about 280 bottom trawls were carried out between depths of 90 and $620 \mathrm{~m}$ (Blacker, 1962). Blacker records the distribution of 107 species and comments on some of the rarer and more unusual species. The gradual extension of national fishery limits to 200 miles resulted in renewed interest in the potential of the deeper waters of the continental slopes to the west of the British Isles. Six exploratory voyages were undertaken in 1973-74, four by the MAFF's FRV Cirolana and two by commercial trawlers chartered by the White Fish Authority (now Seafish Industry Authority) on behalf of MAFF. The area covered extended along the slope from about $50^{\circ} \mathrm{N}$ to $60^{\circ} \mathrm{N}$ and also onto the slopes of many of the offshore banks including Rockall, Hatton, George Bligh, Rosemary, Lousy, Bill Bailey and the west of Faroe Bank. The fishing strategy of the research vessel cruises was to carry out four trawls at each locality at depths of approximately $300,400,500$ and 600 fathoms (549, 732,914 and $1097 \mathrm{~m}$ ). The charter vessel Swanella concentrated its survey on the more northerly areas of the slope and some offshore banks, which had yielded the most promising results (McDiarmid, MS 1974a). The other charter vessel, the Luneda, concentrated on only two areas, that were among those considered to be the most productive, namely the Tory ground (approx. $55^{\circ} \mathrm{N}$ ) and the Flannan ground $\left(58^{\circ} 30^{\prime} \mathrm{N}\right)($ McDiarmid, MS 1974b). A total of 286 trawl hauls were made and Bridger (1978) has published an account of the trawls used, the grounds fished, overall catch rates and has described aspects of the biology of some species. These surveys represent a valuable source of information on the fish populations, which pre-date the commercial exploitation. With the assistance of funding from the European Commission (EC) these data, together with data from a later 1978 survey, have been re-analysed by Gordon and Swan (1997). The highest catch rates were on the eastern slopes of the Rockall Trough between about 54 and $57^{\circ} \mathrm{N}$ (mostly ICES Sub-area VI). The proportion of the catch that comprises what Bridger termed 'trash fish' (species unlikely to be marketable) was greater on the slopes to the west of Ireland. The slopes off southwest Ireland (mainly ICES Sub-area VII) were also much more difficult to fish and Bridger states that "no commercial skipper would have stayed for more than a couple of hauls at most".

The former Federal Republic of Germany also carried out many surveys for deep-water resources in 
the northeastern Atlantic. A total of 12 cruises of the 'Walther Herwig' were carried out between 1974 and 1986 in the Rockall Trough and on the slopes of its surrounding banks. More than 1000 stations were fished with commercial bottom trawls at depths between 200 and $1200 \mathrm{~m}$ in areas where the bottom topography was suitable. Occasionally trawling was carried out at greater depths (Merrett et al., 1991a). Ehrich (1983) has published information on catch rates and biological parameters of the seven species that he considered to be of commercial or potentially commercial importance. These species were Coryphaenoides rupestris (roundnose grenadier), Argentina silus (greater argentine), Chimaera monstrosa (rabbit fish), Molva dypterygia (blue ling), Aphanopus carbo (black scabbardfish), Hoplostethus atlanticus (orange roughy) and Micromesistius poutassou (blue whiting). He carried out separate analyses of the data from the Rockall area (north of $53^{\circ} \mathrm{N}$ ) and what he called the Biscay Area (south of $53^{\circ} \mathrm{N}$ ). In the Rockall area the above species comprised most of the biomass while in the Biscay area, not only was the total biomass less, but the selected species made up less of that biomass. In a more general study of the total catch data for all species, Rätz (1984) divided the area into three and gives pooled abundance and biomass data for each area by $100 \mathrm{~m}$ depth intervals. He also used multivariate techniques to analyse the total catch data in an attempt to identify areas or depths with particular characteristics. Until recently much of the biological data on non-target species was only in notebook form. However, as a contribution to the EC FAIR Deep-fisheries Project (Gordon, 1999a, 2001a) most of these data have been extracted and archived in a database.

Following the commissioning of the oceanographic research vessel RRS Challenger in 1973, the Scottish Association for Marine Science (SAMS) (formerly the Scottish Marine Biological Association (SMBA)) began a deep-water research programme in the Rockall Trough. The deep-water fishing surveys of the continental slope began in 1975 with a series of 5 cruises. These were multidisciplinary cruises of relatively short duration and fishing was limited to two Granton trawl hauls, at depths of 750 and 1000 $\mathrm{m}$, per cruise. The sampling area was the Hebridean Terrace, a large expanse of trawlable slope between about $56-57^{\circ} \mathrm{N}$ and $08-10^{\circ} \mathrm{W}$. One of the important aims of the SMBA survey was to investigate seasonal aspects of the biology of the deep-water species. A further 7 cruises between 1976 and 1979 used the same
Granton trawl to sample at 500 and $1250 \mathrm{~m}$ as well as the standard 750 and $1000 \mathrm{~m}$ hauls. Additional material was also collected over a much wider depth range using a small 8 fathom box trawl fished on a single warp and a $3 \mathrm{~m}$ Agassiz trawl. Full details of the trawls, the station positions and catches for all stations down to $2000 \mathrm{~m}$ are given in Gordon and Swan (1993) and an overview of the general fish ecology is given in Gordon and Duncan (1985a)

In 1978, the U.K. Institute of Oceanography (IOS) began an investigation of the benthos of the Porcupine Seabight off the southwest of Ireland (Rice et al., 1991). SAMS and IOS collaborated on a detailed study of the fish populations of the Seabight using a semiballoon shrimp trawl fished on a single warp to fish the entire slope and the same Granton trawl as was used by SAMS in the Rockall Trough to fish the upper slopes. Between 1978 and 1983 a total of 40 Granton trawls (260-1 $285 \mathrm{~m})$ and 133 semi-balloon trawls (138-4 $587 \mathrm{~m}$ ) were carried out. A description of the gears and the ecology of the fish populations of the Porcupine Seabight resulting from this survey have been published (Merrett et al., 1991a, b).

Between 1983 and 1987 SAMS returned to work in the Rockall Trough and the Granton trawl was used for the last time to fish two stations at $250 \mathrm{~m}$ depth. The main emphasis of the work changed to using a semi-balloon trawl rigged on either a single or on paired warps, to sample a much wider depth range of the slopes of the Rockall Trough. Some experiments, in conjunction with the Marine Biological Association of the U.K., to investigate the effects of attaching artificial lights to the headline of the trawl were also carried out in 1984 and 1885 (Pascoe, 1990; Gordon et al., 2002). The surveys resumed with a new series of six joint benthic/fishing cruises to the Rockall Trough between 1990 and 1992. The main emphasis of the fish work was to collect otoliths for studies on age determination. In 1999 the opportunity was taken to carry out some repeat hauls at $1000 \mathrm{~m}$ depth on the Hebridean Terrace which complements a similar, pre-fishery series made using the same gear and ship as in 1985. This was the last fishing cruise of RRS Challenger before she was decommissioned.

As a result of all the SAMS studies in the Rockall Trough between 1975 and 1979, again between 1983 and 1992 and finally in 1999, there are now complete catch data for 41 Granton trawls, 31 box trawls, 95 semi-balloon trawls fished on both single and paired warps and 73 Agassiz trawls. 
In recent years deep-water surveys to the Rockall Trough have been carried out by the Fisheries Research Services (FRS), Marine Laboratory, Aberdeen. Six cruises between 1996 and 2000 either investigated the behaviour of fishing gears in deepwater, or carried out dedicated deep-water fishery surveys. Some opportunistic deep-water trawling has also been carried out on other FRS surveys, for example, in support of a project on anglerfish (Gordon, 2001b).

Although France carried out some deep-water fishing surveys in the northern part of Rockall Trough in the 1960s little information has been published. In 1996 the new research vessel Thallassa carried out a deep-water trawling survey on the Hebridean Terrace. This particular area was chosen to build on the long time-series of SAMS data from the same area (Allain and Kergoat, 1997; Lorance, 1998). A total of 19 valid tows were carried out at depth ranges between 700 and $1750 \mathrm{~m}$ (Allain, 1999). Thallassa returned to the same area in 1999 and a further 34 hauls were carried out between at depths between 1000 and 2000 m (Lorance, IFREMER, pers. comm).

In 1993 the Irish Marine Institute (Fisheries Research Centre) began a series of deep-water surveys using a chartered commercial trawler (Connolly and Kelly, 1994). The main objective was to sample selected species for biological studies. In November 1995 comparisons were made between the catch and discards of a commercial bottom trawl and longlines (Connolly and Kelly, 1996, MS 1997). The sampling area extended along the continental slope between $58^{\circ} 30^{\prime} \mathrm{N}$ and $54^{\circ} \mathrm{N}$ at depths between 740 and 1400 $\mathrm{m}$. Another trawl survey was carried out in the same area in September 1996 for biological sampling and the estimation of discards (Kelly et al., MS 1997a). A further survey was carried out in 1997 and longline surveys in 1997 and 1999 (Clarke, MS 1999). More recently, beginning in March 2000, the Bord Iascaigh Mhara (BIM) initiated a two-year program of deepwater fishing trials using trawler and longliners, which incorporates scientific data collection (Anon., MS 2002).

Some exploratory fishing has been carried out by the former USSR in the international sector of the northern Rockall Trough and Hatton Bank (Vinnichenko, 2000)

Parts of the northern Rockall Trough and the Wyville Thomson Ridge lie within the Faroese EEZ.
The Fisheries Laboratory has, in the last two decades, carried out exploratory surveys using bottom trawl, longlines, tangle nets and pots (Reinert, 1995).

Norway has traditionally fished by longline along the edge of the continental shelf and onto the upper slope for blue ling (Molva dypterygia), ling (Molva molva) and tusk (Brosme brosme). In 1991 experimental longline surveys were undertaken in deep water along the continental slope to the west of the Hebrides (Olsen, 1995; Stene and Buner, MS 1991). Two stations were within the Rockall Trough, one on the Anton Dorn Bank at depths between 548-684 m and the other on the continental slope to the west of St Kilda at depths between 475-1 $097 \mathrm{~m}$. Information on the catches is given by Stene and Bunner (1991).

From the above account of the surveys of the $20^{\text {th }}$ century, especially since the 1970s, and building on the explorations of the late $19^{\text {th }}$ and early $20^{\text {th }}$ centuries it is clear that the deep-water fish populations of the Rockall Trough must be amongst the most studied of any ocean. The earliest surveys had a very strong bias toward ichthyology and it is equally a concern that some of the later, mainly fisheries orientated, surveys of the $20^{\text {th }}$ century lacked ichthyological experience and as a result some total catch data may be incomplete or inaccurate. Nevertheless, at the species level, and especially for those that are either being exploited or have the potential for exploitation, there are numerous data on geographical and depth ranges, abundance, length frequency distributions, seasonal/annual variations in distribution and catch rates. The interpretation of all the information from these surveys must take into account the fishing gear employed. More detailed considerations of this and also the biology and ecology of the fish species will be dealt with below.

\section{Other Physical and Biological Oceanographical Investigations (Excluding Fish and Fisheries)}

A symposium on the oceanography of the Rockall Channel was held in 1985 and the proceedings, which cover a wide range of topics, were published in 1986 (Mauchline, 1986b). Included in this volume is a detailed bibliography of the Rockall Trough (Mauchline et al., 1986).

Gage (2001) has summarised the studies of the deep-sea benthic environment of the Rockall Trough. The more recent studies were initiated in 1973 by Gage and co-workers at SAMS as part of multi-disciplinary 
study of the Rockall Trough. A time series centred on two permanent stations at 2200 and $2900 \mathrm{~m}$, with opportunistic sampling at other locations and depths.

The Atlantic Frontier Environmental Network (AFEN) is a consortium of oil operators established in 1995, who have collaborated with academic bodies and institutions to carry out widespread environmental assessments of the area to the west of Scotland, including the Rockall Trough, where oil exploration might occur. An account of the scope of the investigations carried out under the auspices of AFEN is to be found in a special issue of Continental Shelf Research (Mordue, 2001). Individual oil companies have also been carrying out their own environmental impact assessments in the Rockall Trough (e.g. Jones, 1998).

The U.K. Natural Environment Research Council (NERC) funded a Land Ocean Interaction Study (LOIS), a component of which was a Shelf Edge Study (SES) carried out on the Hebridean Terrace in the Rockall Trough (Mitchell et al., 1997).

A study of the biogeochemistry in the deep ocean benthic boundary (BENBO) was also funded by the NERC between 1997 and 2000 (Black, 2001; Black et al., 2001). The general aim of the project was to investigate the physical, chemical and biological processes occurring in a relatively undisturbed marine environment. Two of the study sites were within the Rockall Trough, one at the entrance at a depth of $3580 \mathrm{~m}$ and another in the northwest at $1920 \mathrm{~m}$.

\section{Biology and Ecology of Deep-water Fishes}

There have been numerous studies of the biology and ecology of the deep-water fishes of the Rockall Trough. As the commercial fishery developed the emphasis has increasingly changed to studies on target species. The following account is not intended to be a comprehensive bibliography but simply an indication of some of the important results. The publications cited should enable the interested reader to source further information.

\section{General ecological accounts}

An overview of some of the key questions concerning environmental and biological aspects of slope-dwelling fishes, that utilises many examples from the Rockall Trough, is to be found in Gordon et al. (1995).
The first attempt to examine the structure of the fish assemblages of the Rockall Trough was by Rätz (1984). Using cluster analysis on a sub-set of the German survey data (8 cruises between 1979 and 1983) he showed that the 298 hauls could be grouped into 11 clusters with geographical location and depth being the main determinants. Later, using the full German data set, Stehmann (EC Deep-fisheries Project, Gordon, 1999a) recognised eight sub-areas in the Rockall Trough and its immediate surroundings. These sub-areas were defined in relation to the topography, the sea floor substrate and its associated benthic fauna and the hydrography. Only five of these areas were truly in the Rockall Trough. Depth distribution, abundance and other biological parameters of the dominant fish species were described in relation to these areas.

These studies had the advantage of only using one type of bottom trawl (a second smaller trawl of similar design was used occasionally). In the SAMS surveys in the northern Rockall Trough several quite different trawls were used between 1975 and 1992 and differences in catch composition between them were quite evident. Gordon and Duncan (1985a) and Gordon (1986) gave some preliminary comparisons of catch composition between gears. Later Gordon and Bergstad (1992) used multivariate analysis to compare the catches of three different otter trawls. The most important factors determining the catch composition and abundance were depth, followed by net type. The greatest difference between gears was in the catch of the smallest trawl, which was fished on a single warp. This gear was less effective at catching the larger more mobile species, such as sharks, and yielded large catches of the small synaphobranchid eel, Synaphobranchus kaupi. Similar comparisons of trawl catch composition in relation to fishing gear were carried out in the Porcupine Seabight (Merrett et al., 1991a). Gordon et al. (1996) compared the catch composition by gear type and bathymetric zone between the Rockall Trough and the Porcupine Seabight.

Connolly and Kelly (1996a) compared the differences in catch composition and catch rates between trawl and longline. The longline catches of the Rockall Trough tend to be dominated by elasmobranchs and the gadiform fishes.

Although this review is primarily concerned with demersal fishes, the publications on the mesopelagic 
fishes by Kawaguchi and Mauchline (1982, 1987) provide a source of information on these families. Merrett et al. (1986) used large pelagic trawls both in the water column and over the slope at depths between 100 and $1000 \mathrm{~m}$. Demersal species made only a small contribution to the catches of the pelagic trawls.

\section{Main target species}

\section{Molva dypterygia (blue ling)}

Although it was the exploitation of $M$. dypterygia that was one of the key factors in the development of the recent deep-water trawl fishery of the Rockall Trough, there have been relatively few biological studies on the species. The results of a Nordic study on Molva molva (ling), M. dyterygia and Brosme brosme (tusk) in the northeast Atlantic, including the Rockall Trough, are given by Bergstad and Hareide (1996) and Magnússon et al. (1997). Age estimation, especially of the adults, is difficult but progress is being made (Bergstad et al., 1998). German studies in the Rockall Trough are described by Ehrich (1983) and in adjacent areas by Thomas (1987). U.K. studies include those by Bridger (1978) and Gordon and Swan (1993; 1997). The diet was described by Mauchline and Gordon (1984a)

\section{Coryphaenoides rupestris (Roundnose grenadier)}

General accounts of survey abundance, length frequency and depth distributions of $C$. rupestris are given by Bridger (1978), Ehrich (1983), Gordon (1979a) and Gordon and Swan (1993; 1997a). The age and growth of this species has been described by Gordon (MS 1978); Kelly et al. (1997b); Allain and Lorance (2000) and Lorance et al. (2001). Gordon and Swan (1996) and Swan and Gordon (2001) validated the ages of juvenile fish. The reproduction has been the subject of studies by Kelly et al. (1996) and Allain (2001). The diet in the Rockall Trough was described by Mauchline and Gordon (1984b).

\section{Aphanopus carbo (black scabbardfish)}

General accounts of survey abundance, length frequency and depth distributions of $A$. carbo are given by Bridger (1978), Ehrich (1983) and Gordon and Swan $(1993,1997)$. Unvalidated age estimates of fish caught off Madeira suggest a faster growth rate than many other deep-water species (Morales-Nin and Sena-Carvalho, 1995). Similar results, including some from the Rockall Trough, were obtained from a recent European Commission Study Contract Environment and biology of deep-water species, Aphanopus carbo (Lowe, 1839) in NE Atlantic: basis for its management (BASBLACK) (Santos, 2000; Morales-Nin et al., 2002). The diet has been described by Mauchline and Gordon, (1984c). The eggs and early juveniles of this species are unknown and the fish in the Rockall Trough were all immature sub-adults.

\section{Hoplostethus atlanticus (orange roughy)}

General accounts of survey abundance, length frequency and depth distributions of $H$. atlanticus are given by Bridger (1978), Ehrich (1983), and Gordon and Swan (1993, 1997), although some of the data in Bridger (1978) are incorrect because some catches of $H$. atlanticus were ascribed to a different species. The identification problem has now been resolved (Merrett and Wheeler, 1983). None of these surveys encountered the large spawning aggregations that typify the global fisheries for this species, although some large catches around the Rosemary Bank were reported by a German commercial trawler in 1979 (Freytag, 1979). H. atlanticus is the most quoted example of a long lived, >100 y, deep-water fish although the age estimates are not without controversy (Tracy and Horn, 1999; Branch, 2001). Ages estimated from both whole and sectioned otoliths from the Rockall Trough suggest a similar longevity to the South Pacific stocks (Allain and Lorance, 2000). Gordon and Duncan (1987a) have described aspects of the biology of $H$. atlanticus and $H$. mediterraneus in the Rockall Trough and Mauchline and Gordon (1984c) described the diet. The spawning periodicity of $H$. atlanticus in the Rockall Trough has been described by Du Buit (1995). Some information on length at first maturity and fecundity is given in the report of the EC Deep-fisheries Project (Gordon, 1999a).

Exploited deep-water sharks; Centroscymnus coelolepis (Portuguese dogfish) and Centrophorus squamosus (Leaf scale gulper shark).

General accounts of survey abundance, length frequency and depth distributions of $C$. coelolepis and C. squamosus are given by Bridger (1978), Gordon and Swan (1993; 1997, MS 1997). Unvalidated age estimates of $C$. squamosus using the dorsal spines has been carried out by Clarke (2000a) and Clarke et al. (2002). Clarke (2000a), Girard and Du Buit (1999), Girard et al. (2000a) and Clarke et al.(2001) have investigated aspects of the reproduction of both species. The diets of both species have been described by Mauchline and Gordon (1983a). 
Other species of minor commercial or no commercial value

Data on the distribution and abundance of deepwater sharks in the Rockall Trough have been collated by Gordon and Swan (MS 1997) and Gordon (1999b). Data on length distributions of deep-water sharks and chimaerids are included in the study of their diet by Mauchline and Gordon (1983a). Gordon and Duncan (1989) have described the distribution and diet of the deep-water rays. Clarke (2000b) has described some of the rarer chondrichthyan fishes of the Rockall Trough.

The alepocephalid fishes are a dominant family in the Rockall Trough. Alepocephalus bairdii and $A$. rostrata are the dominant species although the latter is only abundant and at shallower depths in the southern part of the Trough. These species can comprise a high proportion of the catch that is discarded. The other species of the family tend to be deeper living and in lower abundance with a greater number of species in southern areas (c.f. Gordon and Duncan, 1985a; Gordon, 1986; Merrett et al., 1991a, b). Allain and Lorance (2000) and Allain (2001) have described the age, growth and the reproduction of $A$. bairdii. The diets of the upper slope species have been described by Mauchline and Gordon (1983b).

Argentina silus is exploited in a semi-pelagic fishery and aspects of its biology in the north-eastern Atlantic are described by Wood and Raitt (1968). Ehrich (1983) described the distribution and abundance in the Rockall Trough. Heessen and Kuiter (MS 1991) have described aspects of the biology including age and reproduction and Mauchline and Gordon (1983b) have described the diet.

There are several species of deep-water eels in the Rockall Trough but Synaphobranchus kaupi and, at abyssal depths, Histiobranchus bathybius are the only abundant species. S. kaupi has a very wide depth distribution and in surveys using fine meshed trawls is the most abundant species in the Rockall Trough (Gordon and Bergstad, 1992; Gordon et al., 1996 and Merrett et al., 1991a). Gordon and Mauchline (1996) have described the distribution and diet of S. kaupi in the Rockall Trough.

The notacanthid fishes (spiny eels), especially Notacanthus bonapartei and Polyacanthonotus rissoanus can be abundant at certain depths. Their biology has been described by Coggan et al. (1998).
The macrourid fishes are the most diverse and among the most abundant of the fishes of the Rockall Trough. Coryphaenoides rupestris has been described above. Gordon (1979b,c) gives some preliminary information on their reproduction. The biology of Nezumia aequalis was described by Coggan et al. (1999). The diet of the macrourid fishes of the Rockall Trough was described by Mauchline and Gordon (1984b) and for some of the deeper living species by Gordon and Duncan (1987b). The latter paper also gives some data on the seasonality of reproduction, especially for Coryphaenoides guentheri. Swan and Gordon (2001) have estimated ages of juvenile macrourids and, for some species, have validated these ages using marginal increment analysis.

The gadid fishes tend to be associated with the upper slope. The information on Molva molva and Brosme brosme has recently been collated by Bergstad and Hareide (1996) and Magnússon et al. (1997). Micromesistius poutassou is a deep-water semipelagic species, which is heavily exploited along the margins of the Rockall Trough. Its biology was described by Bailey (1982) and more recent updates of its fishery-related biology can be found in the reports of the ICES Advisory Committee for Fisheries Management (ACFM) (e.g. Anon., 2001a). The diets of the gadid fishes, including Phycis blennoides (greater forkbeard), have been described by Mauchline and Gordon (1984a). The biology of the closely related morid fishes (Lepidion eques, Halrgyreus johnsonii, Antimora rostrata and Mora moro) has been investigated by Gordon and Duncan (1985b) and the diets were described by Mauchline and Gordon (1980, 1984a).

Aspects of the age, growth and reproduction of the scorpaenid, Helicolenus dactylopterus (bluemouth), have been described by Kelly et al., (1999) and the reproduction by Allain (2001). Allain and Lorance (2000) have also estimated the age of this species.

There have been many studies of the biology of the flatfishes, Lepidorhombus whiffiagonis (megrim) and L. boscii (four spot megrim), in the neighbouring Celtic Sea. Aspects of the distribution, age composition and reproduction of $L$. whiffiagonis in the deeper waters of the Rockall Trough have being investigated in a EC Project entitled Distribution and Biology of anglerfish and megrim in the waters to the west of Scotland (Gordon, 2001b). The diet of L. whiffiagonis in the Rockall Trough has been described by (Du Buit, 1984). 
There are two species of anglerfish Lophius piscatorius and L. budegassa in the Rockall Trough, but the former is much more abundant. They are generally considered to be shelf species, but are now known to occur to depths of at least $1000 \mathrm{~m}$. Detailed studies on L. piscatorius in both shallow and deepwater have been carried out during the EC project mentioned above (Gordon, 2001b).

\section{Trophic ecology}

The above account of the more important studies on the fishes of the Rockall Trough does not adequately describe the work that has been done on the trophic ecology of the fishes. The diets of over 70 fish have been described in a series of papers (Coggan et al., 1998; Gordon and Duncan, 1985b, 1987a, b, 1989; Gordon and Mauchline 1996; Kawaguchi and Mauchline 1982, 1987; Mauchline and Gordon, 1980, $1983 \mathrm{a}, \mathrm{b}, 1984 \mathrm{a}, \mathrm{b}, \mathrm{c})$. The occurrence of stones, sediment and fish scales in the stomachs was described by Mauchline and Gordon (1984d) and the parasites by Mauchline and Gordon (1984e). Mauchline and Gordon $(1985,1986)$ investigated the trophic diversity and the foraging strategy of the deep-water fish assemblages. Gordon and Duncan (1987b) constructed simple food webs for the fish assemblages at 2200 and $2900 \mathrm{~m}$ in the Rockall Trough. The general conclusion from all these studies of diet and feeding behaviour is that the demersal fish of the slopes feed mainly on pelagic or benthopelagic prey rather on than benthic organisms. Gordon and Mauchline (1990) showed how the different prey categories were apportioned according to the best estimates of total fish biomass by bathymetric zone. In the Rockall Trough total fish abundance and biomass tends to increase with increasing depth to peak at about 1000 to $1250 \mathrm{~m}$ depth and thereafter declines. The peak coincides with the peak in the mesopelagic biomass and the role of horizontal and vertical impingement of the mesopelagic fauna onto the slope as a food source for benthopelagic fishes has been discussed by Mauchline and Gordon (1991) and Gordon (2001c).

\section{Trace Metals and Hydrocarbons}

There have been a number of studies on the trace metals of the deep-water fishes of the Rockall Trough (Cronin et al., 1998; Mormede and Davies, MS 1998, 2001a, b; Vas, 1991; Vas and Gordon, 1988, 1993; Vas et al., 1993). The levels of polychlorobiphenyl and pesticide residues in Aphanopus carbo and Lophius piscatorius from the Rockall Trough were determined by Mormede and Davies (2000, 2001c).

\section{Deep-water Fisheries}

The development and current status of the deepwater fisheries of the Rockall Trough, based mainly on the reports of the ICES Study Group on the Biology and Assessment of Deep-sea Fishery Resources (SGDEEP), were reviewed by Gordon (2001c) and only a brief summary will be given here. The deepwater bottom trawl fisheries in the northeast Atlantic began with the exploitation of Coryphaenoides rupestris and other species by Russian trawlers in the late-1960s. Most of the effort was probably south of Iceland and on the Reykjanes Ridge, although some also occurred in the northern Rockall Trough (Pechenik and Troyanovsky, 1970). The Rockall Trough deep-water, bottom trawl fishery began in the 1970s when German vessels began to exploit spawning aggregations of Molva dypterygia. After a few years, German interest decreased and the French fleet gradually moved into deeper waters and began to exploit M. dypterygia. In 1989 the French fishery increased as they began to develop markets for deepwater species such as C. rupestris, Aphanopus carbo and deep-water sharks (Charuau et al., 1995). The fishery continued to develop and gradually moved into deeper waters. It was the discovery of the high valued, Hoplostethus atlanticus in 1992 that probably brought the deep-water fishery to public attention and stimulated other nations to become involved. However, the fishery continues to be dominated by France. The main interest of the Scottish fleet is the exploitation of the high value anglerfish (Lophius spp.). Recently, Ireland has been renewing its fishing fleet and deepwater fisheries are expanding.

The semi-pelagic trawl fishery takes place mainly along the eastern slopes of the Rockall Trough and targets spawning aggregations of either Micromesistius poutassou or Argentina silus.

The static gear fisheries within the Rockall Trough are by longline and mainly comprise a Spanish and U.K. fleet targeting Merluccius merluccius with deep-water sharks as a by-catch and a Norwegian fleet targeting Molva molva, M. dypterygia and Brosme brosme.

The accuracy of landings data for deep-water species is a problem, especially if the reporting systems either did not have or still do not have the facility to record at the species level. However, as most of the deep-water landings from the Rockall Trough are from the French bottom trawl fishery there are good national records of landings. 
The monitoring of landings of deep-water species from the Rockall Trough at the ports began at the start of the fishery and the EC Deep-fisheries Project became the focus for more comprehensive sampling. The following brief account is compiled from the Project report (Gordon, 1999a). France began to sample the landings of Coryphaenoides rupestris in 1990 and as a contribution to the Project routine monthly sampling of length composition of the landings from ICES Sub-areas VI and VII was carried out at the French port of Lorient. Otoliths were collected for age estimation. Hoplostethus atlanticus were sampled at the port of Boulogne sur mer, which complimented earlier sampling at the ports of Concarneau and Lorient. At the time of the Project the landings of the deep-water sharks, Centrophorus squamosus and Centroscymnus coelolepis, were combined as 'siki'. Monthly sampling at French ports, especially Concarneau, has determined the seasonal and annual proportions of the two species in the landings and provided information on length composition and sex ratio.

The Scottish sampling during the Project concentrated on the landings of French vessels at the Scottish port of Lochinver. A wide range of deep-water species were measured and weighed and otoliths were collected for age estimation. The weight measurements were particularly useful for calculating lengthweight relationships, which are often lacking for deepwater species. Monthly sampling of the deep-water sharks is continuing as a contribution to a Ph.D. Project (Crozier, MS 2001).

Data on the landings of deep-water species are generally reported by ICES Sub-areas or Divisions, which were formulated for the assessment and management of shelf fisheries and which often have a political significance. These are mostly unsuitable for deep-water fisheries and these problems were recognised at the start of the Deep-fisheries Project. An alternative division of the ICES area into deepwater fishing zones based on topography and hydrography was proposed (Coggan, MS 1997) but was never implemented.

The Rockall Trough lies within ICES Sub-areas VI and VII and a part of Div. Vb. However, landings data for Sub-area VI include those from the slopes to the west of the Rockall Bank and a part of the Hatton Bank (Division VIb). The remainder of the Hatton bank lies within Sub-area XII, a vast undivided area that extends westwards to include the Mid-Atlantic
Ridge. Large parts of Div. VIb and XII are in international waters, the more so since the U.K. renounced its claim to a 200-mile fishery zone around Rockall in 1997. It is a concern that not all landings from international waters are being reported and that there may be misreporting between Sub-areas VI and XII (Anon., MS 2000a).

On a finer scale EU Logbooks contain data, which is reported by ICES Statistical rectangles ( $1 / 2$ degree of latitude and one degree of longitude), but the value of these data is diminished because depth is not recorded. It is possible for a statistical rectangle covering the shelf edge or in area of seamounts or underwater ridges to have a depth range of more than $1000 \mathrm{~m}$.

With the exception of Molva dypterygia, over 90\% of the landings from the deep-water mixed bottom trawl fisheries in the Rockall Trough are by French vessels that target different species at different depths throughout the year. Allain (1999) gives a good description of the French fleet and the evolution of the fishery. Different parts of the fleet have developed and declined in different ways, the efficiency of some sectors of the fleet has undoubtedly increased and there have been changes in target species as markets have developed. As a result it would be difficult to estimate a meaningful catch per unit of effort (CPUE) for the whole fleet. To overcome this problem Girard et al. (2000b) and Lorance and Dupouy (2001) sub-divided the fleet and used some assumptions to determine the directed effort on each species. It is the trends in CPUE indices for this sector of the fleet that has changed least since the start of the fishery that, in the absence of aged based data, has been used for stock assessment.

At any given depth on the slope of the Rockall Trough a fine meshed, research trawl is likely to catch about 40 or 50 different species of benthopelagic fishes. A relatively small number of these species comprise most of the biomass (Gordon and Mauchline, 1990). Most of the marketable species are amongst the top ranking species in terms of biomass, but this depends on area and depth. The proportion of marketable species amongst the top ranking species tends to be less in the southern areas and at the greatest depths. The body shape (bulbous heads and elongate bodies) of deep-water fishes results in the retention of many immature fish by trawls that have cod-end mesh sizes appropriate for shelf fishes. Fish caught by the trawl and subsequently discarded will not survive. There were two studies of discarding in the 
Rockall Trough carried out under the auspices of the EC Deep-fisheries Project. France carried out quarterly sampling of discards by placing observers on commercial trawlers that were targeting $C$. rupestris (Dupouy et al., MS 1998). Three species dominated the discards; Deania calceus (birdbeak dogfish), C. rupestris and Alepocephalus bairdii. The $C$. rupestris discarded were the smaller individuals and accounted for about $30 \%$ by weight of the total catch of this species. Overall the total discards of all species were close to $50 \%$. The Scottish discard sampling was carried out by placing observers on both Scottish and French trawlers (Blasdale and Newton, MS 1998). The composition of the discards and the discard rates differed between the two fleets because the French fleet fishes over a wider depth range. The Scottish fleet of smaller vessels tends to fish on the upper slope where Lophius is an important target species.

Many deep-water fishes have large scales and are not well endowed with mucus so most immature fish or fish of small adult size that enter the trawl and subsequently escape through the meshes will likely be badly damaged and will probably not survive. Gordon and Hunter (MS 1994) described these fish as 'no-catch discards'. Gordon (MS 1997) estimated that the escapees from commercial trawls could be as high as 66 to $86 \%$ in terms of numbers and 10 and $45 \%$ in terms of weight depending on fishing depth.

\section{Assessment and Status of the Stocks}

It was undoubtedly the unregulated development of the deep-water trawl fishery in the Rockall Trough that in 1992 led the Council of Fisheries Ministers of the European Union to initiate and support measures leading to a better understanding of deep-water fisheries (Gordon, MS 1998). At the same time ICES also recognised the growing importance of these new fisheries and in 1994 inaugurated the ICES SGDEEP, which has met in plenary every second year. The 1994 and 1996 meetings of the Study Group were mainly concerned with the collection of data (Anon., MS 1995, MS 1996) and it was not until 1998 and again in 2000 that assessments were attempted. (Anon., MS 1998, 2000a). In 2001 the group became a Working Group (WGDEEP) and reported by correspondence (Anon., MS 2001c). In the absence of adequate age data these assessments were for the most part based on the directed time-series of CPUE, which, in the case of the Rockall Trough, were derived from a portion of the French fleet. Surplus production and modified DeLury models were used for some of the assessments. The methodology, results and the various caveats and assumptions have been described by Large et al. (2002). The conclusion of the Study Group, based on 1998 data, was that most of the deep-water species were being exploited at levels that were outside safe biological limits. A change in the configuration of the French database in 1999 meant that at the time of the 2002 meeting of WGDEEP it was not possible to update the time-series of directed CPUE (Anon., MS 2002b). Instead CPUE data were provided based on the total effort of the French fleet. As a result WGDEEP were not able to update previous assessments.

\section{Fishing Impacts}

In general terms deep-water fishes have a high age at maturity and there is the suggestion that some species may not begin spawning until somatic growth has all but ceased (Gordon et al., 1995). In the Rockall Trough the fishery only began increasing about 10 years ago and if, as often appears to be the case, maturity is not reached until an age of more than 10 years then the present catches are of fish that are the product of the almost unexploited, pre-fishery spawning stock. Because of their body shape many fish are caught and discarded before they reach maturity. The probable high mortality of even younger fish caused by the damage sustained while escaping through the meshes will also have an effect on recruitment. The combination of these factors must mean that the biomass will decline more rapidly than might be the case for a shelf stock

In the Rockall Trough abundance indices, expressed as CPUE, have declined by as much as $50 \%$ in five years for the principal deep-water species (Lorance and Dupouy, 2001). In addition to changes in abundance a new fishery on a virgin stock might be expected to result in changes in length composition and age/length at maturity. There is no clear evidence from the Rockall Trough to suggest that there have been changes in length composition, but this is perhaps not surprising given the longevity of most of the species involved and the short history of the fishery. Even in longer established deep-water fisheries, for example Hoplostethus atlanticus in New Zealand (Clark, 2001) and Squalus mitsukurii in the Pacific (Wilson and Seki, 1994), size changes have not been observed. However, in an upper slope mixed trawl fishery off Australia it appears that there has been a reduction in total biomass and in the size of most fish stocks over a period of 20 years (Graham et al., 1997). A marked decline in the abundance of 
older/larger fish was also reported. The short time scale of the Rockall Trough fishery and the longevity of the fish also means that it is too early for any possible changes in reproductive strategies to be detectable.

Changes at the total fish assemblage level are more difficult to detect. Although there are numerous surveys in the Rockall Trough that pre-date and span the period of the fishery the use of different fishing gears in different areas and at different depths and also doubts about the completeness and accuracy of the total catch data for some of the earlier surveys makes it difficult to draw any firm conclusions on long term change. In 1985 SAMS carried out a series of trawl hauls using a semi-balloon otter trawl fished on a single warp at $1000 \mathrm{~m}$ in the Rockall Trough. The purpose of this series was to investigate the effect on catches of attaching artificial lights to the headline. The control hauls with no lights attached provide a replicate series at the same location and depth and pre-date the rapid increase in the present fishery that began in 1989. In 1999 SAMS returned to this area and using the same ship and trawl carried out a further five valid trawls (see below for gear damage). The data from these pre- and post-fishery surveys are presently being analysed in detail for publication. These data, together with other survey data, were used in a report on the effects of fishing on deep-water fish species to the west of Britain (Basson et al., 2002). A preliminary multivariate analysis of the total catch data suggests that there have been changes between 1985 and 1999. The crustacean catch appears to show greater changes, possibly with a shift towards more scavenging species, but the analysis is more complex because of the added dimension of diurnal vertical migration (Gordon, unpubl. data). There are indications that there has been a decline in fish diversity but not in taxonomic distinctness. Although there were some indications of changes in size spectra they were not conclusive.

The ecosystem effects of fishing activity can be defined as follows (Pope and Symes, 2000):

a) causes mortality on target fish species and incidentally on other biota

b) makes food available to other species in the ecosystem by: discarding unwanted catch of fish and benthos, discarding wastes and killing and damaging animals in the path of the gear during its deployment

c) disturbs the seabed through the action of some fishing gears

d) generates litter composed of lost or discarded gear as well as other non-specific debris.

e) modifies predator-prey relationships, thereby changing the flow of energy through parts of the system and the modification of habitats

The mortality of target species and other biota by bottom trawls has been described above. It is estimated that there will be a high mortality of all fish species entering a trawl irrespective of whether they are retained or escape. Discards are generally returned as dead whole organisms to the area where they were caught and, although some will be removed by birds and the pelagic fauna, it is likely that a considerable proportion arrives back on the seabed. Since discards make up a considerable part of the total catch, this is a significant input of organic material to the seabed. The extent to which benthic epifauna and infauna is destroyed or damaged by the physical impact of the trawls is unknown but it is likely that this will also provide a further significant input of non-living organic matter. Such inputs might be expected to benefit scavengers and indeed a study on the Australian slope suggested that, over a twenty-year period, discarding from a trawl fishery may have resulted in a proliferation of crabs (Graham et al., 1997).

Disturbance of the seabed as a result of the action of fishing gear is of increasing concern and there were many papers published on the subject in a recent ICES Symposium on the Ecosystem Effects of Fishing (Hollingworth, 2000). Only one paper considered the ecosystem effects of fishing in deep-water (Koslow et $a l ., 2000)$. The effects of deep-water fishing activities on seamounts and their hard-bottom faunas, including corals, has been investigated in the South Pacific (see Koslow et al., 2001 and Clark, 1999 for recent accounts in Australian and New Zealand waters respectively). The damage to deep-water coral reefs off the coast of Norway and their subsequent protection is well documented (Fosså et al., 2002). There are many reports of the occurrence of patches of deepwater corals in the Rockall Trough (see Rogers (1999) for a review). However, a lack of knowledge on the true extent of their distribution, both past and present, and of their ability to recover from damage makes it difficult to assess the impact of the fisheries on corals and other hard bottom communities. In some instances modest fishing effort may even serve to distribute fragments of living coral and result in the formation of new colonies (Rogers, 1999). However, in most cases the physical damage and the smothering by sediment are likely to cause the destruction of the colony. The AFEN surveys discovered the Darwin Mounds in the northern Rockall Trough in 1998 (Bett 
MS 1999, 2001). These mounds, which are about 100 $\mathrm{m}$ across and up to $6 \mathrm{~m}$ high, are widely distributed over an area of about 60 square kilometers and support colonies of deep-water corals. More recent studies on the environment and ecology of the mounds have also revealed damage by trawling (Bett et al., 2001). Some information on the distribution of Lophelia and other corals in the northern Rockall Trough and around the Faroe Islands resulting from the Nordic BIOFAR programme is given by Bruntse and Tendal (2001).

While damage to hard bottom substrates may be the most obvious and readily explainable impact of fishing, it has to be recognised that most deep-water trawling takes place in areas of soft-bottomed sediments. Few fishermen, unless by accident or while searching for new grounds, will risk damaging their trawls by fishing on hard ground unless the rewards are high. In the Rockall Trough this usually means fishing at greater depths for Hoplostethus atlanticus. The impact of trawling on deep-sea soft bottom sediments and their biota is virtually unknown. However, photographic surveys frequently reveal the presence of trawl marks on the seabed. In one such survey in the Rockall Trough such marks were visible in 2 to $12 \%$ of all photographs at depths between 700 and $1300 \mathrm{~m}$ (Roberts et al., 2000). Evidence of trawl marks was also found during the AFEN surveys (Bett, 2000). At the start of any fishery on a virgin stock the initial catch rates will be high but will soon decrease as the accumulated biomass of older fish is removed. To maintain catch levels the fishing effort will increase and as a consequence the seabed will be subjected to even greater disturbance. Some of the best fishing grounds in the Rockall Trough are along the narrow continental margin to the west of Scotland and the fishing impacts, further concentrated by depth constraints, are likely to be quite substantial. Between 1975 and 1992 SAMS carried out many bottom trawl surveys on the Hebridean Terrace using several types of otter trawl and a beam (Agassiz) trawl. At depths greater than about $600 \mathrm{~m}$ there was never any damage to the trawl and only occasionally were small stones caught by the net. The most sampled area was the $1000 \mathrm{~m}$ contour and in 1999 an attempt to repeat a series of bottom trawls at this depth using the same net that was used very successfully between 1983 and 1987 resulted in the loss of two trawls and only 5 valid tows. The trawls were severely damaged as a result of large stones entering the net. These stones, measuring up to $1.5 \mathrm{~m}$ in diameter, were relatively free of encrusting organisms and were almost certainly glacial erratics that had been lying buried in the sediment. Intense commercial trawling activity, using heavy rockhopper bottom gear, has probably dislodged them and deposited them on the surface. Another anthropogenic impact that manifests itself especially in the deeper water at the entrance to the Rockall Trough is the presence of clinker thrown overboard from steamships.

The loss of fishing gear, especially traps or gill nets, in deep water and the resulting ghost fishing has been recognised as a problem (Hopper, 1995a). In shallow water these gears will relatively quickly become fouled or otherwise inactivated but in deep water they may continue to ghost fish for many years.

How deep-water fishing might modify predatorprey relationships, thereby changing the flow of energy through parts of the system and alter the habitats is an interesting question. If there is an almost total mortality of all fish entering the trawl whether or not they are retained or escape through the meshes, then it is likely that the biomass of all species will be declining. Other fishing gears, such as longlines, are much more selective for the larger species that are usually also the top predators. Life history characteristics will also mediate how the system will respond to large-scale removals. For example the low fecundity, live-bearing sharks will be more vulnerable than a species with a high fecundity that produces large numbers of eggs. On the other hand a wide spatial distribution into areas that are not fished may help to protect some species.

Perhaps the most immediate change in predator prey relationships might be in response to the input of discards and other dead organisms. The SAMS time series of sampling suggests that there may have been an increase in the relative abundance of Synaphobranchus kaupi. S. kaupi is considered to be a scavenging species (Gordon and Mauchline, 1996). It is perhaps too early, in view of the longevity of most of the fish species, to detect any significant changes as a result of fishing activities. However, the long time-series of biological sampling in the Rockall Trough, albeit using different gears, is a unique archive of data that pre-dates the fishery and will be increasingly important as the effects of fishing manifest themselves either on the fish stocks or on the whole ecosystem.

The deep-water fishery exploits benthopelagic species whose diet is very largely composed of benthopelagic and pelagic species. The vertical and horizontal impingement of the mesopelagic fauna onto the slope is considered to be an important food source. 
A decrease in the benthopelagic consumers may manifest itself in changes in the pelagic ecosystem. Large-scale fisheries for Micromesistius poutassou and Argentina silus must also have an impact on deepwater food chains. While the emphasis on investigations of the demersal fish stocks and benthic baseline studies for the oil industry is understandable, it is unfortunate that there has been a decline in pelagic research.

Clearly there are many concerns about the ecosystem effects of deep-water fisheries and these are succinctly summarised by the ICES Working Group on Ecosystem Effects of Fishing Activities (Anon., MS 2000b). The Working Group notes that the effects of fishing gears on habitats are generally the most long lasting and irreversible of all effects of fishing on ecosystems. The Working Group considers that deep water habitats are likely to be highly vulnerable and urges ICES to "attach priority in its advice, and management agencies in their regulations, to ensuring that these new and expanding fisheries are kept sustainable both with regard to mortalities inflicted on all species (target and non-target) and effects on habitats".

\section{Management}

The only management tool currently in force for the 'new' deep-water species of the Rockall Trough is a restriction of effort regulation that is applicable within European Community waters. It came into force in January 1996 and limits and apportions the effort by gear type to certain member states. The allowable effort is generous and there is no evidence that the regulation has ever been enforced.

The present assessments of deep-water species in the ICES area are based on stocks that are defined by an area and a species. These stocks may have little relevance to the biological stocks and there have been no attempts at multi-species assessments. In general ICES Sub-areas are often inappropriate for deep-water stock delimitation (see above) but in the case of the Rockall Trough, with the exception of the most westerly parts of ICES Div. VIb, the management unit of Sub-areas VI and VII and Div. Vb probably has some biological validity for many species. Virtually nothing is known of the biological stock structure of deep-water species in the ICES area and it has been recognised as an important area for future research (Anon., MS 2000c).
In 1992 the European Commission recognised the potential vulnerability of deep-water resources and, following a meeting in 1993, which considered possible management options, noted that "a precautionary approach should be taken in the development of new fisheries or the enhancement of many of the existing fisheries" (Anon., MS 1993). An international workshop on deep-water fisheries, supported by NATO and the EC, drew on experience from other regions and advised extreme caution in the exploitation of these resources (Hopper, 1995a, b). The advice from ICES ACFM based on the SGDEEP reports has consistently been that "a cautious approach should be adopted" and that "fishing effort should be kept at a low level until sufficient information is gathered from existing fisheries to enable scientifically-based management decisions" (Anon., MS 1995).

Following the first assessments by the Study Group in 1998 (Anon., MS 1998), ACFM began to give advice for the main species and continued to advise caution for the other species (Anon., 1999). As a result of the Study Group's assessments in 2000 based on 1998 CPUE data (Anon., MS 2000a), ACFM gave even more specific advice for the management of the main species (Anon., 2001a). The status of the key species of the Rockall Trough and the ICES management advice is summarised below. The proposed reference points were $U_{p a}(50 \%$ of virgin biomass) and $U_{\text {lim }}$ (20\% of virgin biomass).

\section{Molva dypterygia}

The SGDEEP assessment of $M$. dypterygia for the Rockall Trough in 1998 was based on the data from French commercial trawlers that accounted for $>90 \%$ of the landings of this species from Sub-area VI. The landings from Sub-area VII are a small by-catch and are either a separate species or a sub-species. In the absence of any definitive data on stock discrimination and despite many uncertainties, the fish in Sub-area VI were considered to be a separate stock. The trend in commercial CPUE and abundance indices for the selected French trawler fleet indicated a marked decline for both parameters. The results from the assessment models were unreliable but nevertheless SGDEEP was able to conclude that the current exploitable biomass (U) was considered to be below $U_{\text {lim }}$. The advice from ACFM was that fishing mortality (F) be reduced and that the possibility of reducing effort on the spawning grounds be considered 
(Anon., 1999). The assessment by SGDEEP in 2000 combined data from Sub-areas V, VI and VII and came to the same conclusions (Anon., MS 2000a). The group noted an increase in Scottish fishing effort and that there was a trend for a decrease in the abundance of larger fish in the landings. The advice from ACFM was that there should be no directed fisheries on this stock and that measures be implemented to reduce/ minimise catches in the mixed fisheries (Anon., 2001a).

\section{Coryphaenoides rupestris}

The SGDEEP 1998 assessment was based on the French standardised CPUE data for ICES Sub-areas VI and VII, a swept area method using historical survey data, a pseudo-cohort analysis based on catch at age data for 1996 and 1997 (Lorance et al., 2001) and an Irish estimate based on adjusting population indices to absolute values using survey data. The conclusion, which recognises the limitations of the data, was that the current biomass was above that of the proposed precautionary reference point $\left(U_{p a}\right)$ (Anon., MS 1998). In its advice on management ICES ACFM gave no specific comment but simply reiterated its standard precautionary comment of that year. "ICES recommends immediate reduction in fisheries that cannot be shown to be sustainable. All remaining fishing activity should be conducted in the context of effective management which emphasises documentation of fishing activity, and which can react appropriately to biological characteristics of the populations" (Anon., 1999). SGDEEP included Div. $\mathrm{Vb}$ in the 2000 assessment and concluded, again emphasising the limitations of the data, that the stocks were now below $U_{p q}$ and close to $U_{l i m}$. On the basis of this assessment ICES ACFM recommended an immediate reduction in fishing effort by $50 \%$ for Subareas VI and VII and Div. Vb combined (Anon., 2001a).

\section{Aphanopus carbo}

In 1998 SGDEEP considered that the time-series of data for ICES Sub-area VI was too short to carry out a reliable assessment and ACFM issued its standard precautionary advice. In 2000 SGDEEP, whilst recognising the short time-series and a lack of knowledge of the stock structure and migration, considered the "northern component" as being below $U_{p a}$ and possibly below $U_{l i m}$ (Anon., MS 2000a). In 2000, ACFM recommended a reduction in fishing effort by $50 \%$ to bring catch down to around MSY (Anon., 2001a)

\section{Hoplostethus atlanticus}

SGDEEP 1998 recognised the problems associated with the CPUE data for an aggregating species targeted by only a small part of the fleet but nevertheless concluded that the stocks in Sub-area VI were below $U_{\text {lim }}$ and in Sub-area VII below $U_{p a}$ In 1998 ACFM issued its standard precautionary advice. SGDEEP concluded in 2000 that the stock in Subarea VI was close to $U_{\text {lim }}$ but considered that the results from Sub-area VII were too unreliable to be used to give advice. It was considered that the current level of landings was the result of the sequential discovery and depletion of aggregations. The ICES ACFM 2000 advice was that "orange roughy stocks can only sustain very low rates of exploitation. ICES repeats its general recommendation - that fisheries on such species be permitted to expand very slowly, and are accompanied by programs to collect data which allow evaluation of stock status" (Anon., 2001a).

\section{General Advice}

In addition to providing the above advice on these and other deep-water species ACFM was requested to give answers to specific requests from the North East Atlantic Fisheries Commission (NEAFC) and the EC. NEAFC asked what further information was needed to provide a basis for comprehensive management measures to conserve deep-water species and what interim management measures could be introduced based on existing biological information. In reply ACFM expressed its concerns about the accuracy of the reporting of landings, assessments based on short time-series of CPUE that in some cases were not being updated, the high mortality of discards and escapees, and the uncertainties about stock discrimination. As an interim management measure ACFM considered that a "stringent reduction of fishing effort" might be effective. Since many of the fisheries are mixed fisheries, they considered that a TAC regulation was "not very likely to be effective". Whilst longlining is effective in some specialised areas, it was not considered to be a viable alternative to trawling. ACFM was doubtful of the efficacy of closed areas both for biological and enforcement reasons (Anon., 2001a). In 1993 the EC had considered licensing as a possible conservation measure (Anon., MS 1993) and this was again considered by ACFM who phrased it as follows. "An immediate step towards effectively controlling the fishery could be the strict regulation of the numbers of boats, trawl-hours or numbers of hooks per day, etc. Because, there is virtually no overlap with conventional shelf species there would 
be no conflict with any existing management measures. However, this can hardly be seen as an interim measure but rather as a medium termmeasure." As an interim measure, ACFM suggested working towards effort reduction and at the same time supporting the continuation of the CPUE series.

The EC requested ICES to provide advice on possible management measures to be applied to deepwater species. In particular, ICES was requested to indicate the probable utility of application of (1) TACs, (2) geographical and/or temporal closures, (3) other technical measures including appropriate mesh size, hook size and gear structure and (4) effort limitation. In addition, ICES was requested to comment on environmental impacts created as a result of fishing for deep-water species and to advise on possibilities for reducing or eliminating such effects. ACFM structured its reply into a series of 13 points some of which were dealt with in more detail in an annex. As a prelude to the reply, they highlight the fact that there had been numerous warnings and recommendations to adopt the precautionary approach and that these had gone unheeded. As a result, most of the stocks were already over-exploited and it was too late to adopt the precautionary approach. ACFM concluded that "the immediate threat is that stocks may be fished down before the status of the stocks can be assessed. Compared to the economic damage of fishing down resources, a zero TAC for a few years might be a tolerable measure to prevent damage to the most sensitive habitats." ACFM recognised that it was the deep-sea ecosystem, including the fish stocks that were sensitive and required protection. They considered that no single management measure was likely to be effective. Closed areas were only likely to be of value as a long-term measure and much more research was necessary to assess how they might function in the deep-sea. (In this context, a report of an expert workshop on "Managing risks to biodiversity and the environment on the high sea, including tools such as marine protected areas - scientific requirements and legal aspects" highlights some of the difficulties of closed areas (Thiel and Koslow, 2001)). Gear limitation, especially a trawl ban for selected species/ areas, was considered to be a useful measure. It could also be used as a measure to prevent the fishery moving into new areas. ACFM recognised that drastic reductions in catches were unavoidable and suggested setting TACs on the basis of $1-2 \%$ of virgin biomass per year. However, they recognise that some species may be less vulnerable and could withstand a higher rate of exploitation. Many of Europe's deep-water fisheries are mixed fisheries and it was recognized that using TACs as the primary management tool would be difficult. The low levels of TAC required could render the fishery unviable for fleets solely dependent on the deep-water resource and varying quotas for different species could lead to more incentive to discard, high-grade or misreport. They concluded that "implementation of TACs for deepwater stocks, not accompanied by other measures, probably would not prevent deep-sea ecosystems suffering adverse impacts." ACFM states that a general licensing system should be implemented by the EC. This should be combined with TACs, seasonal and area closures and possibly with gear limitation. The remaining points are all concerned with the need for strict and effective enforcement, comprehensive data collection, surveys and research, support for studies on ecosystem effects and maintaining a dialogue between managers, the industry and scientists.

In the July 2000 the EC issued a press statement stating that it was concerned about the state of the deep-water fish stocks and that there was a need for quick action to prevent irreversible damage caused by unregulated fisheries. It further stated that it was proposing to recommend to European Council of Fisheries Ministers in December 2000 that TACs be introduced from January 2001. Several NGOs drew the Commission's attention to the advice from ACFM that questioned the value of TACs. In reply, the EC pointed out that TACs were a step in the right direction and that to implement other measures would be unrealistic within the available time scale because of the "institutional requirements to be observed". The proposals were announced on 1 December 2000 and included suggested TACs for all the main species of the Rockall Trough and an allocation to the member states on the basis of previous track record. These allocations were made for the whole northeast Atlantic area and not for specific ICES Sub-areas such as VI and VII (Rockall Trough). The net result of this was that the TACs were proposed for community waters and waters not under the sovereignty or jurisdiction of third countries in ICES Sub-areas I through XIV. The proposed quotas were based on a $20 \%$ reduction of the catches for the 1989-98 period. For example, the TAC for Coryphaenoides rupestris was allocated between seven European countries. France by virtue of her fishery in the Rockall Trough was allocated $72 \%$ of the catch, Denmark was allocated $18 \%$ for her Skagerrak fishery and Spain 7\% for her fishery in international waters. The U.K. and Ireland were 
allocated 0.6 and $0.2 \%$ of the catch respectively. By setting the quota for the whole ICES area, it would have precluded unregulated fishing by EU vessels in international waters. Prior to the meeting of the Council of Fisheries Ministers, it became obvious from press reports that there was going to be opposition to the proposed TACs for deep-water species from the U.K. and Ireland. In the event, the Council decided to postpone the setting of TACs for a year to allow more time to collect information and scientific advice. They also decided that, to prevent a rush to build up historical track records, the 2000 and 2001 catches would not be taken into account when setting such TACs.

Although almost all of the Rockall Trough lies within European Community waters, it is very probable that there is continuity with the stocks on the slopes to the west of the Rockall Plateau and the Hatton Bank. Before the U.K. renounced its claim to a 200-mile exclusive fishery zone around Rockall, the fisheries on most of these slopes, although not regulated, were controlled in the sense that access was restricted to certain EU countries or by third party agreements. Now that these areas, which include parts of the northern Rockall Trough, are in international waters, they have been subjected to unregulated fishing. Much of the attention has focused on the exploitation of haddock on the Rockall Bank by, amongst others, Russia (Anon., 2001b). However, Russia also has a long history of deep-water exploratory fishing in the areas outside the 200-mile zone dating back to 1965 (Vinnichenko, MS 2000) and is now moving into the areas that have become international waters (Vinnichenko and Khlivnoy, MS 2001). Vinnichenko and Khlivnoy, MS 2001) provide some information on the deep-water fisheries in ICES Div. VIb and Vb. Spain (Durán Muñoz et al., MS 2000) and the Faroe islands (Thomsen, MS 1998, MS 1999) have both developed deep-water fisheries in international waters, including the Hatton Bank.

NEAFC recognized the seriousness of the 1998 ICES management advice on deep-water species and held an open hearing hosted by the European Commission in 1999. Since then NEAFC has made little progress to effect any management in international waters. At the Annual Meeting of NEAFC in November 2000, the EU stressed the vulnerability of the stocks and "the importance for NEAFC to take responsibility". The EU also suggested that NEAFC "should open up a discussion of different regulatory measures, such as effort limitations, closed areas, gear limitations or any combination of these. According to the EU, scientific advice on some of these species is somewhat inconsistent and contradictory. To make progress, more information is required for managers to be able to fully comprehend the advice needed and transparency must be increased" (Anon., $2001 \mathrm{~b}$ ). It is these remarks by the EU that probably prompted NEAFC to request further advice from ICES.

The request by NEAFC to ICES was as follows:

a) Characterise and classify the most important deep-sea species according to their life-history strategies and rank them by vulnerability to exploitation together with more well-known deepsea species, e.g. redfish and Greenland halibut,

b) Clarify advice statements for stocks where little biological information is available in order to generate consistency of advice,

c) Give established reference points for statements on stock status,

d) Provide advice on how to improve data-collecting systems and advise on appropriate improvements for monitoring deep-sea resources.

The ranking of the species according to several life history parameters was carried out by WGDEEP (Anon., MS 2001) and the results were compiled into a simple table by ACFM (Anon., 2001c). Of the species relevant to the Rockall Trough, the most vulnerable were the deep-water sharks and Hoplostethus atlanticus. Coryphaenoides rupestris was at an intermediate level and the least vulnerable were Aphanopus carbo, Molva molva, M. dypterygia and Brosme brosme. ICES advised that this information on life history parameters is useful but not a perfect guide to sustainable management.

NEAFC, in the Annex to their request for advice, give details of the specific areas that they considered to be lacking in clarity. One area of concern was the apparently contradictory statements of advice for species where there was little biological information. These were "ICES recommends immediate reduction in these fisheries unless they can be shown to be sustainable" and "consistent with a precautionary approach fishing should not be allowed to expand faster than the acquisition of information necessary to provide a basis for sustainable exploitation". In reply ICES ACFM (Anon., 2001c) explained that the first statement applied to those fisheries that are already considered to be harvested outside safe biological limits (Category 2). The second statement 
referred to new fisheries that may develop on virgin stocks or where only a limited part of the stock has been exploited (Category 1). Where the state of a stock is unknown, such as the deep-water sharks, then Category 1 advice applied. It is possible for some species for the advice to fall into both categories. For example, the 'stock' of Hoplostethus atlanticus in Subarea VI is category 2 while the 'stocks' of this species in all other areas are category 1. ICES also gave its justification for continuing to use the reference points first proposed by SGDEEP in 1998, but state that it would keep these under review as scientific knowledge accumulates. ICES, together with NEAFC and national governments, are currently reviewing reporting procedures.

In October 2001 a sub group on deep-sea fisheries of the European Commission's Scientific, Technical and Economic Committee for Fisheries (STEFC) met to review the status of deep-water fisheries in European Union waters and to provide management and conservation advice. The report endorsed the view of ICES ACFM that TACs were not likely to be an effective management tool. Instead they recommended that they should only be used as an ad hoc emergency measure pending the introduction of effort control. In December the EC proposed a new system of TACs based on previous track record and allocated between ICES Sub-areas or groups of Sub-areas and announced their intention to propose effort control regulations in early 2002. For some species such as Coryphaenoides rupestris the TAC applied to the whole of the Rockall Trough (ICES Sub-areas VI and VII and Div. $\mathrm{Vb}$ ) while for others such as Aphanopus carbo and the deep-water sharks the management unit extended from the continental margin westwards to the Mid Atlantic Ridge. Hoplostethus atlanticus, which was considered to have a more localised distribution, had separate TACs for Sub-areas VI and VII.

At the meeting of Fisheries Ministers in December the TAC proposal was simply noted. The Commission published a proposal for a regulation to establish specific access requirements and associated conditions applicable to fishing for deep-sea stocks in March 2002. If implemented the regulation would include the requirement for a deep-sea fishing permit, effort restrictions, logbooks detailing the gear and fishing operations, vessel monitoring and landing at designated ports. In addition, the Commission recognises the need for improved scientific data and proposes that observers be assigned to vessels with a deep-sea fishing permit.

At their meeting in November 2001 NEAFC agreed to set up a Working Group on appraisal of Regulatory Measures for Deep-sea Species. This will take place in June $2002^{1}$.

\section{Conclusions}

The Rockall Trough is probably one of the beststudied deep-water ecoystems. The fisheries that developed during the 1990s are well documented and have been accompanied by relevant research, especially on distribution, age and reproduction. It is unfortunate, and a cause for concern within the ICES Working Group, that this international research and monitoring is not being continued at the same level into the $21^{\text {st }}$ Century. Much raw data remains to be analysed and there is a need to initiate new studies on stock discrimination and ecosystem effects of fishing activities. Despite the documented concerns about the status of the stocks and the repeated warnings about the need for caution from numerous sources, no action has been taken to regulate the fishery or seriously address ecosystem effects of the fishery, which at present levels is unsustainable.

There is general agreement amongst scientists, the fishing industry and the politicians that the fragile, deep-water stocks are seriously overexploited but political imperatives dictate that uncertainties and inconsistencies in the scientific assessment and advice are used to postpone the urgent action that is required. It is perhaps not much of a consolation, but we know a lot about the ecosystem that is being destroyed in the Rockall Trough, while in other areas, such as the Hatton Bank, we will never know what is being destroyed.

\section{Acknowledgements}

The author is grateful to the Scottish Association for Marine Science (SAMS) for its support of his research on the deep-water fish of the Rockall Trough from 1975 to the present. However, the views

\footnotetext{
1 The European Union has agreed to introduce quotas for most deep-water species effective from January 2003. Other regulatory measures, such as licensing and vessel monitoring, will also be introduced. At their annual meeting in November 2002, NEAFC introduced a temporary freeze on fishing effort for deep-water species in their area as a prelude to more permanent management measures for these fisheries.
} 
expressed in this paper are those of the author and do not represent the policy of SAMS or any other organisation that has helped to fund the research.

\section{References}

ALLAIN, V. 1999. Écologie, biologie et exploitation des populations de poissons profonds de l'Atlantique du nordest. Theses de Doctorat de L'Unversite de Bretagne Occidentale, 310 p. + annexes

2001. Reproductive strategies of three deep-water benthopelagic fishes from the northeast Atlantic Ocean. Fish. Res., 51: 165-176.

ALLAIN, V. and B. KERGOAT. 1997. Biodiversite et strategies demographiques des populations de poissons profonds de l'atlantique nord-est soumises a la pression de la peche. Vie Milieu., 47: 285-294.

ALLAIN, V. and P. LORANCE. 2000. Age estimation and growth of some deep-sea fish from the northeast Atlantic Ocean. Cybium, 24(suppl.): 7-16.

ANON. 1974. West of Scotland Pilot. West coast of Scotland from Mull of Galloway to Cape Wrath including the Inner and Outer Hebrides and off-lying islands. $11^{\text {th }}$ Edition, N.P.66, The Hydrographer of the Navy, U.K.

MS 1993. Deep-water Fisheries (Commission Staff Working Paper). Commission of the European Communities, SEC(93) 1791, Brussels, 10 November 1993, 28 p.

MS 1995. Report of the study group on the biology and assessment of deep-sea fisheries resources for 1994. ICES C.M. Doc., No. Assess:4, 91 p.

1995. Report of the ICES Advisory Committee on Fishery Management 1994. ICES Coop. Res. Rep., 210, $222 \mathrm{p}$.

MS 1996. Report of the study group on the biology and assessment of deep-sea fisheries resources for 1996. ICES C.M. Doc., No. Assess:8, 145 p.

MS 1998. Report of the study group on the biology and assessment of deep-sea fisheries resources for 1998 . ICES C.M. Doc., No. ACFM:12, 172 p.

1999. Report of the ICES Advisory Committee on Fishery Management 1998. ICES Coop. Res. Rep., 229(2), $446 \mathrm{p}$.

MS 2000a. Report of the study group on the biology and assessment of deep-sea fisheries resources. ICES C.M. Doc., No. ACFM:8, 206 p.

MS 2000b. Report of the Working Group on Ecosystem Effects of Fishing Activities. ICES C.M. Doc., No. ACME:02, 93 p.

MS 2000c. Report of the working group on the application of genetics in fisheries and mariculture. ICES C.M. Doc., No. F:03, 53 p.

2001a. Report of the ICES Advisory Committee on Fishery Management, 2000. ICES Coop. Res. Rep., 242, $911 \mathrm{p}$.

2001b. Report of the nineteenth Annual Meeting of the North-east Atlantic Fisheries Commission, London, 21-24 November 2000. Published by the Office of the Commission, London, U.K., 85 p. 2001c. Report of the ICES Advisory Committee on Fishery Management, 2001. ICES Coop. Res. Rep., 246, $895 \mathrm{p}$.

MS 2001. Report of the Working Group on Biology and Assessment of Deep-sea Fisheries Resources (BIM) (by correspondence). ICES C.M. Doc., No. ACFM:23, $38 \mathrm{p}$.

MS 2002a. Deepwater Programme 2001. Scientific Report to ICES WGDEEP 2002, 18 pp. + 3 Appendices.

MS 2002b. Report of the Working Group on Biology and Assessment of Deep-Sea Fisheries Resources. ICES C.M. Doc., ACFM:16, 243 p.

BAILEY, R. S. 1982. The population biology of blue whiting in the North Atlantic. Adv. Mar. Biol., 19: 257-355.

BASSON, M., J. D. M. GORDON, P. A. LARGE, P. LORANCE, J. G. POPE. and B. RACKHAM. 2002. The Effects of fishing on Deep-water Fish Species to the West of Britain. Joint Nature Conservation Committee, Report No. 324, 150 p.

BERGSTAD, O. A., and N.-R HAREIDE. 1996. Ling, blue ling and tusk of the north-east Atlantic. Fisken og havet, $15,126 \mathrm{p}$.

BERGSTAD, O. A., J. V. MAGNUSSON, J. MAGNUSSON, N-R. HAREIDE, and J. REINERT. 1998. Intercalibration of age readings of ling (Molva molva L.), blue ling (Molva dypterygia Pennant, 1784) and tusk (Brosme brosme L.). ICES J. Mar. Sci., 55: 309-318.

BETT, B. J. MS 1999. RRS Charles Darwin Cruise 112C, 19 May-24 June 1998. Atlantic Margin Environmental Survey: seabed survey of deep-water areas $\left(17^{\text {th }}\right.$ round Tranches) to the north and west of Scotland. Southampton Oceanography Centre Cruise Report, No. $25,171 \mathrm{p}$.

2000. Signs and symptoms of deepwater trawling on the Atlantic Margin. In: Man-made objects on the seafloor 2000. Published by The Society for Underwater Technology, p. 107-118.

2001. U.K. Atlantic Margin Environmental Survey: introduction and overview of bathyal benthic ecology. Cont. Shelf Res., 21: 917-956.

BETT, B. J., D. S. M. BILLETT, D. G. MASSON and P. A. TYLER. MS 2001. RRS Discovery Cruise 248, 07 July10 August 2000. A multidisiplinary study of the environment and ecology of deep-water coral ecosystems and associated seabed facies and features (The Darwin Mounds, Porcupine Bank and Porcupine Seabight). Southampton Oceanography Centre Cruise Report, No. 36,52 p. + charts.

BLACK, K. 2001. Final Report BENBO, Biogeochemistry in the deep ocean benthic boundary. NERC Thematic Programme, 1997-2000. Natural Environment Research Council, $24 \mathrm{p}$.

BLACK, K. S., G. R. FONES, O. C., PEPPE, H. A., KENNEDY, and I. BENTALEB. 2001. An autonomous benthic lander: preliminary observations from the U.K. BENBO thematic programme. Cont. Shelf Res., 21: 859-877.

BLACKER, R. W. 1962. Rare fishes from the Atlantic slope fishing grounds. Ann. Mag. Nat., Hist, 13: 261-271.

1982. Rockall and its fishery. Lab. Leafl., MAFF 
Direct. Fish. Res., Lowestoft, 55, 23 p.

BLASDALE, T., and A. W. NEWTON. MS 1998. Estimates of discards from two deepwater fleets in the Rockall Trough. ICES C.M. Doc., No. O:11, 18 p.

BRANCH, T.A. 2001. A review of orange roughy (Hoplostethus atlanticus) estimation methods, biology and stock structure. In: A decade of Namibian Fisheries Science. A. I. L. Payne, S. C. Pillar, and R. J. M. Crawford, (eds.), S. Afr. J. Mar. Sci., 23: 181-203.

BRIDGER, J. P. 1978. New deep-water trawling grounds to the west of Britain. Lab. Leafl., MAFF Direct. Fish. Res, Lowestoft, 41, $40 \mathrm{p}$.

BRUNTSE, G., and O. S. TENDAL, 2001. Lophelia pertusa and other cold water corals in the Faroe area. In: Marine biological investigations and assemblages of benthic invertebrates from the Faroe Islands. G. Bruntse, and O. S. Tendal, (eds.), Kalbak Marine Biological Laboratory, p. 22-32.

CHARUAU, A, H. DUPOUY and P. LORANCE. 1995. French exploitation of the deep-water fisheries of the North Atlantic. In: Deep-water Fisheries of the North Atlantic Oceanic Slope. A. G. Hopper (ed.), Netherlands, Kluwer Academic Publishers, p. 337-356.

CLARK, M. 1999. Fisheries for orange roughy (Hoplostethus atlanticus) on seamounts in New Zealand. Oceanol. Acta, 22: 593-602.

2001. Are deepwater fisheries sustainable? - the example of orange roughy (Hoplostethus atlanticus) in New Zealand. Fish. Res., 51: 123-135.

CLARKE, M. MS 1999. Deepwater longline survey. Marine Institute, Ireland, Demersal Survey Report, No. 5.

CLARKE, M. 2000a. Aspects of the biology of three exploited deepwater sharks Centrophorus squamosus, Centroscymnus coelolepis and Deania calceus (Elasmobranchii:Squalidae) from the continental slopes of the Rockall Trough and Porcupine Bank. PhD Thesis, National University of Ireland, 286 p.

CLARKE, M. W. 2000b. Records of deep water chondrichthyan fish caught on long-line in the Rockall Trough. J. Mar. Biol. Assoc. U.K., 80: 337-378.

CLARKE, M. W., P. L. CONNOLLY, and J .J. BRACKEN. 2001. Aspects of reproduction of the deep water sharks Centroscymnus coelolepis and Centroscymnus squamosus from west of Ireland and Scotland. J. Mar. Biol. Ass. U. K., 81: 1019-1029.

2002. Age estimation of the exploited deepwater shark Centrophorus squamosus from the continental slopes of the Rockall Trough and Porcupine Bank. J. Fish. Biol., 60: 501-514.

COGGAN, R. A. MS 1997. Designation of fishing areas in the North-east Atlantic for deep-water fisheries surveys. ICES C.M. Doc., No. Y:11, 4 p.

COGGAN, R. A., J. D. M. GORDON, and N. R. MERRETT. 1998. Abundance distribution reproduction and diet of notacanthid fishes from the north-east Atlantic. J. Fish Biol., 52: 1038-1057.

1999. Aspects of the biology of Nezumia aequalis from the continental slope west of the British Isles. $J$. Fish Biol., 54: 152-170.
CONNOLLY, P. L., and C. KELLY. MS 1994. Sampling surveys for deep water demersal fish in 1993. Fishery Leaflet, $163,20 \mathrm{p}$.

1996. Catch and discards from experimental trawl and longline fishing in the deep water of the Rockall Trough. J. Fish Biol., 49 (Supplement A): 132-144.

MS 1997. Trawl and longline sampling surveys for deep-water demersal fish in 1995. Fisheries Leaflet, No. $173,20 \mathrm{p}$.

CRONIN, M., I. M. DAVIES, A. NEWTON, J. M. PIRIE, G. TOPPING, and S. SWAN. 1998. Trace metal concentrations in deep sea fish from the North Atlantic. Mar. Environ. Res., 45: 225-238.

CROZIER, P. MS 2001. Distribution and reproductive biology of two species of deepwater squalid shark, Centroscymnus coelolepis and Centrophorus squamosus, in the Rockall Trough area of the Northeast Atlantic. NAFO SCR Doc., No. 105, Serial No. N4493, $5 \mathrm{p}$.

CURRIE, R. I. 1986. Introduction: early investigations in the Rockall Channel. Proc. R. Soc. Edinb., 88B: 1-3.

DEACON, M. 1977. Staff-Commander Tizard's journal and the voyages of HM Ships Knight Errant and Triton to the Wyville Thomson Ridge in 1880 and 1882. In: A Voyage of Discovery. M. Angel (ed.), Pergamon Press, London, p. 1-14.

DU BUIT, M. H. 1984. Predation de la Cardine (Lepidorhombus whiffiagonis W.) au nord et a l'ouest de l'Ecosse. ICES J. Cons., 41: 194-198.

1995. Notes preliminaires sur la ponte de l'hoplostethe (Hoplostethus atlanticus, Trachichthyidae) a l'ouest des iles Britanniques. Cybium, 19: 199-200.

DUPOUY, H., V. ALLAIN, and B. KERGOAT. MS 1998. The discards of roundnose grenadier in the French fishery in ICES Subareas VI and VII. ICES C.M. Doc., No. O:20, $10 \mathrm{p}$.

DURÁN MUÑOZ, P, E. ROMÁN, and F. GONZÁLEZ. MS 2000. Results of a deep-water experimental fishing in the North Atlantic: an example of cooperative research with the fishing industry. ICES C.M. Doc., No. W:04, $15 \mathrm{p}$.

EHRICH, S. 1983. On the occurrence of some fish species at the slopes of the Rockall Trough. Arch. Fischereiwiss., 33: $105-150$.

FARRAN, G. P. 1924. Seventh Report on the fishes of the Irish Atlantic Slope. The Macrourid fishes (Coryphaenoididae). Proc. Roy. Irish Acad., 36B: 91143.

FREYTAG, G. 1979. Bemerkenswerte Anlandung einer Tiefseefischart. Informationen fur die Fischwirtschaft, 26, $72 \mathrm{p}$.

FORBES, E. 1844. Report on the Mollusca and Radiata of the Aegean Sea and on their distribution, considered as bearing on geology. Report of the $13^{\text {th }}$ meeting of the British Association for the Advancement of Science, York, 1843, p. 130-193.

FOSSÅ, J. H., P. B. MORTENSEN and D. M. FUREVIK, 2002. The deep-water coral Lophelia pertusa in Norwegian waters: distribution and fishery impacts. 
Hydrobiologia, 471: 1-12.

GAGE, J. D. 1986. The benthic fauna of the Rockall Trough: regional distribution and bathymetric zonation. Proc. $R$. Soc. Edinb., 88B: 159-174.

2001. Deep-sea benthic community and environmental impact assessment at the Atlantic Frontier. Cont. Shelf Res., 21: 957-986.

GIRARD, M., and M. H. DU BUIT. 1999. Reproductive biology of two deep-water sharks from the British Isles, Centroscymnus coelolepis and Centrophorus squamosus (Chondrichthyes: Squalidae). J. Mar. Biol. Ass. U.K., 79: 923-931.

GIRARD, M., P. RIVALAN, and G. SINQUIN. 2000a. Testis and sperm morphology in two deep-water squaloid sharks, Centroscymnus coelolepis and Centrophorus squamosus. J. Fish Biol., 57: 1575-1589.

GIRARD, M, P. LORANCE, and A. BISEAU. $2000 \mathrm{~b}$. Captures par unité d'effort des espèces profondes du talus continental à l'ouest des îles Britannique. Cybium, 24 (Suppl.): 97-104.

GORDON, J. D. M. MS 1978. Some notes on the biology of the roundnose grenadier Coryphaenoides rupestris to the west of Scotland. ICES C.M. Doc., G:40, 13 p.

1979a. The depth distribution of roundnose grenadier (Coryphaenoides rupestris Gunnerus) on the west of Scotland slope. Ann. Biol., 34: 225-226.

1979b. Seasonal reproduction in deep-sea fish. In: Cyclic phenomena in marine plants and animals. E. Naylor and R. G. Hartnoll (eds.), Pergamon Press, Oxford, p. 223-229.

1979c. Lifestyle and phenology in deep sea anacanthine teleosts. Sym. Zool. Soc. Lond., 44: 327-359.

1986. The fish populations of the Rockall Trough. Proc. R. Soc. Edinb., 88B: 191-204.

MS 1997. A desk study for Highlands and Islands Enterprise on deep-water shrimps in the waters to the west of the British Isles. Scottish Association for Marine Science (Unpubl. manuscript).

MS 1998. Deep-water fish and fisheries in the northeastern Atlantic and Mediterranean: an overview of the EC FAIR Deep Fisheries Project. ICES C.M. Doc., $\mathrm{O}: 18,14 \mathrm{p}$.

1999a. Final Consolidated Report of European Commission FAIR Contract 95 0655. Developing deepwater fisheries: data for the assessment of their interaction with and impact on a fragile environment, $1090 \mathrm{p}$.

1999b. Management considerations of deep-water shark fisheries. In: Case studies of the management of elasmobranch fisheries. R. Shotton (ed.). FAO Fish. Tech. Pap., 378: 77-818.

2001a. Deep-water fish and fisheries: introduction. Fish. Res., 51: 105-111.

2001b. Distribution and biology of anglerfish and megrim in the waters to the west of Scotland. Final report of EC DGXIV Study Contract 98/096.

2001c. Deep-water fisheries at the Atlantic Frontier. Cont. Shelf Res., 21: 987-1003.

GORDON, J. D. M., and O. A. BERGSTAD. 1992. Species composition of demersal fish in the Rockall Trough
North-eastern Atlantic as determined by different trawls. J. Mar. Biol. Ass. U.K., 72: 213-230.

GORDON, J. D. M., and J. A. R. DUNCAN. 1985a. The ecology of the deep-sea benthic and benthopelagic fish on the slopes of the Rockall Trough northeastern Atlantic. Prog. Oceanogr., 15: 37-69.

1985b. The biology of fish of the family Moridae in the deep-water of the Rockall Trough. J. Mar. Biol. Ass. U.K., 65: 475-485.

1987a. Aspects of the biology of Hoplostethus atlanticus and H. mediterraneus (Pisces: Berycomorphi) from the slopes of the Rockall Trough and the Porcupine Sea Bight (North-Eastern Atlantic). J. Mar. Biol. Ass. U.K., 67: 119-133.

1987b. Deep-sea bottom-living fishes at two repeat stations at 2200 and $2900 \mathrm{~m}$ in the Rockall Trough, northeastern Atlantic Ocean. Mar. Biol., 96: 309-325.

1989. A note on the distribution and diet of deepwater rays (Rajidae) in an area of the Rockall Trough. $J$. Mar. Biol. Ass. U.K., 69: 655-658.

GORDON, J. D. M. and J. E. HUNTER. MS 1994. Study of the deep-water fish stocks to the west of Scotland. Volume 1. Final report presented to Highlands and Islands Enterprise and other sponsors. Scottish Association for Marine Science (Unpubl. manuscript), 182 p.

GORDON, J. D. M., and J. MAUCHLINE. 1990. Depthrelated trends in diet of a deep-sea bottom-living fish assemblage of the Rockall Trough. Proceedings of the $24^{\text {th }}$ European Marine Biology Symposium. In: Trophic Relationships in the Marine Environment. M. Barnes and R. N. Gibson (eds.), Aberdeen, Aberdeen University Press, p. 439-452.

1996. The distribution and diet of the dominant, slope dwelling eel, Synaphobranchus kaupi, of the Rockall Trough. J. Mar. Biol. Ass. U.K., 76: 493-503.

GORDON, J. D. M., and S. C. SWAN. 1993. Biological parameters of deep-water fish species. Final Report of EC DG XIV/C/1 Study Contract No. 1992/10, 122 p. + appendices.

1996. Validation of age readings from otoliths of juvenile roundnose grenadier, Coryphaenoides rupestris, a deep-water macrourid fish. J. Fish Biol., 49 (Supplement A): 289-297.

1997. Deep-water demersal fishes:data for assessment and biological analysis. Final Report of EC DG XIV/C/1 Study Contract, No. 94/017, 208 p.

MS 1997. The distribution and abundance of deepwater sharks on the continental slope to the west of the British Isles. ICES C.M. Doc., No. BB:11, 23 p.

GORDON, J. D. M., O. A. BERGSTAD, and P. L. PASCOE. 2002. The influence of artificial light on the capture of deep-water demersal fish by bottom trawling. J. Mar. Biol. Ass. U.K., 82: 339-344.

GORDON, J. D. M., N. R. MERRETT, and R. L. HAEDRICH. 1995. Environmental and biological aspects of slope-dwelling fishes of the North Atlantic. In: Deepwater Fisheries of the North Atlantic Oceanic Slope. A. G. Hopper (ed.), The Netherlands, Kluwer Academic Publishers, p. 1-26. 
GORDON, J. D. M., N. R. MERRETT, O. A. BERGSTAD, and S. C. SWAN. 1996. A comparison of the deep-water demersal fish assemblages of the Rockall Trough and Porcupine Seabight, eastern North Atlantic: continental slope to rise. J. Fish Biol., 49 (Suppl. A): 217-238.

GRAHAM, K. J., B. R. WOOD, and N. L. ANDREW. 1997. The 1996-97 survey of upper slope trawling grounds between Sydney and Gabo Island (and comparisons with the 1976-77 survey). Kapala Cruise Report No.117, Published by NSW Fisheries, Australia, 96 p.

GREEN, C. 1908/09. The Departments Fishery Cruiser, "Helga". Journal of the Department of Agriculture and Technical Instruction for Ireland, 9: 23-28.

GÜNTHER, A. 1887. Report of the deep-sea fishes collected by HMS. Challenger during the years 1873-76. Report of the Scientific Results of the Voyage of HMS Challenger during the years 1873-1876. Zoology, Vol. XXII, 333 p. + plates.

HEESSEN, H. J. L., and C. J. KUITER. MS 1991. Some observations on greater argentine (Argentina silus) from samples collected in 1990 during an experimental fishery. ICES C.M. Doc., No. H:58, 13 p.

HICKLING, C. F. 1928. The exploratory voyages of the 'Florence Brierley'. Notes on the fish recorded. Ann. Mag. Nat. Hist. Ser., 10, 2(8) 33: 196-209.

HOLLINGWORTH, C. E. (ed.). 2000. Ecosystem effects of fishing. Proceedings of an ICES/SCOR Symposium held in Montpelier, France. 16-19 March 1999. ICES J. Mar. Sci., 57: 465-791.

HOLT, E. W. L. 1892. Survey of fishing grounds, west coast of Ireland, 1890-1891. Report on the results of the fishing operations. Scient. Proc. R. Dubl. Soc., VII (N.S.), Part 4: 225-387.

HOLT, E. W. L., and L. W. BYRNE. 1906. First report on the fishes of the Irish Atlantic slope. Fisheries Ireland Scientific Investigations, 1905, II, 28 p.

1908a. New deep-sea fishes from the south-west coast of Ireland. Ann. Mag. Nat. Hist., 8(1): 86-95.

$1908 \mathrm{~b}$. Second report on the fishes of the Irish Atlantic slope. Fisheries Ireland Scientific Investigations, $1906, \mathbf{V}, 63 \mathrm{p}$.

1909. On some fishes from the Irish Atlantic Slope. XXXV Preliminary note on some fishes from the Irish Atlantic Slope. Ann. Mag. Nat. Hist., 8(3): 279-280.

1910a. Third report on the fishes of the Irish Atlantic slope. The Holocephali and Chimaeras. Fisheries Ireland Scientific Investigations, 1908, IV, 26 p.

H1910b. Fourth report on the fishes of the Irish atlantic slope. List of recorded species, with references. Fisheries Ireland Scientific Investigations, 1908, V,7 p.

1911. Fifth report on the fishes of the Irish Atlantic slope. Fishes of the genus Scopelus. Fisheries Ireland Scientific Investigations, 1910, VI, 33 p.

1913. Sixth report on the fishes of the Irish Atlantic slope. The families Stomiatidae, Sternoptychidae and Salmonidae. Fisheries Ireland Scientific Investigations, $1912,29 \mathrm{p}$.

HOLT, E. W. L., and W.L. CALDERWOOD. 1895. Survey of fishing grounds, west coast of Ireland, 1890-1891.
Report on the rarer fishes. Scient. Trans. R. Dubl. Soc., 5: 361-524.

HOPPER, A. G. 1995a. Workshop sessions - summary of conclusions and recommendations. In: Deep-water Fisheries of the North Atlantic Oceanic Slope. A. G. Hopper (ed.), Kluwer Academic Publishers, The Netherlands, p. 409-416.

1995b. (eds.) Deep-water Fisheries of the North Atlantic Oceanic Slope, Kluwer Academic Publishers, Netherlands, $421 \mathrm{p}$.

JONES, K. J. 1998. Environmental impact survey on behalf of Enterprise Oil Ltd in $17^{\text {th }}$ Round License Block 154/1 $\left(58^{\circ} 50^{\prime}-59^{\circ} 00^{\prime}, 07^{\circ} 48^{\prime}-08^{\circ} 00^{\prime} \mathrm{W}\right)$. Cruise report, RRS Discovery Cruise 230C. 07 February-20 February 1998. Dunstaffnage Marine Laboratory, Oban U.K., 52 p. + photographs.

JONES, E. J. W., R. G. PERRY, and J. L. WILD. 1986. Geology of the Hebridean margin of the Rockall Trough. Proc. R. Soc. Edinb., 88B: 27-51.

KAWAGUCHI, K., and J. MAUCHLINE. 1982. Biology of myctophid fishes (family Myctophidae) in the Rockall Trough, northeastern Atlantic Ocean. Biol. Oceanogr., 1: $337-373$.

1987. Biology of the sternoptychid fishes Rockall Trough northeastern Atlantic Ocean. Biol. Oceanogr., 4: 99-120.

KELLY, C. J., P. L. CONNOLLY, and J. J. BRACKEN. 1996. Maturity, oocyte dynamics and fecundity of the roundnose grenadier from the Rockall Trough. J. Fish Biol., 49 (Supplement A): 5-17.

KELLY, C. J., M. CLARKE, and P. L. CONNOLLY. MS 1997a. Catch and discards from a deep-water trawl survey in 1996. Fishery Leaflet, 175, 16 p.

KELLY, C. J., P. L. CONNOLLY, and J. J. BRACKEN. 1997b. Age estimation, growth, maturity and distribution of the roundnose grenadier from the Rockall trough. J. Fish Biol., 50, 17 p.

1999. Age estimation, growth, maturity, and distribution of the bluemouth rockfish Helicoleneus $d$. dactylopterus (Delaroche 1809) from the Rockall Trough. ICES J. Mar. Sci., 56: 61-74.

KOSLOW, J. A., G. W. BOEHLERT, J. D. M. GORDON, R. L. HAEDRICH, P. LORANCE, and N. PARIN. 2000. Continental slope and deep-sea fisheries: implications for a fragile ecosystem. ICES J. Mar. Sci., 57: 548-557.

KOSLOW, J. A., K. GOWLETT-HOLMES, J. K. LOWRY, T. O'HARA, G. C. B. POORE, and A. WILLIAMS. 2001. Seamount benthic macrofauna off southern Tasmania: community structure and impacts of trawling. Mar. Ecol. Prog. Ser., 213: 111-225.

LARGE, P. A., C. HAMMER, O. A. BERGSTAD, J. D. M. GORDON, and P. LORANCE. 2003. Deep-water fisheries of the northeast Atlantic: II Assessment and management approaches. J. Northw. Atl. Fish. Sci., 31: $151-163$ (this volume).

LORANCE, P. 1998. Structure du peuplement ichtyologique du talus continental à l'ouest des îles Britanniques et impact de la peche. Cybium, 22: 309-331.

LORANCE, P., and H. DUPOUY. 2001. CPUE abundance 
indices of the main target species of the French deepwater fishery in ICES Sub-areas V-VII. Fish. Res., 51: 137-149.

LORANCE, P, H. DUPOUY, and V. ALLAIN. 2001. Assessment of the roundnose grenadier (Coryphaenoides rupestris) stock in the Rockall Trough and neighbouring areas (ICES Sub-areas V-VII). Fish. Res., 51: 151-163.

MAGNÚSSON, J. V., O. A. BERGSTAD, N-R. HAREIDE, J. MAGNÚSSON, and J. REINERT. 1997. Ling, blue ling and tusk of the northeast Atlantic. TemaNord, 535, $61 \mathrm{p}$.

MAUCHLINE, J. 1986a. A review of the ecology of the deepwater pelagic fauna of the Rockall Trough. Proc. R. Soc. Edinb., 88B: 145-157.

1986b. The oceanography of the Rockall Channel. Proc. R. Soc. Edinb., 88B: 356 p.

MAUCHLINE, J., and J. D. M. GORDON. 1980. The food and feeding of the deep-sea morid fish Lepidion eques (Günther 1887) in the Rockall Trough. J. Mar. Biol. Ass. U.K., 60: 1053-1059.

1983a. Diets of the sharks and chimaeroids of the Rockall Trough, northeastern Atlantic Ocean. Mar. Biol., 75: 269-278.

1983b. Diets of clupeoid, stomiatoid and salmonoid fish of the Rockall Trough, northeastern Atlantic Ocean. Mar. Biol., 77: 67-78.

1984a. Feeding and bathymetric distribution of the gadoid and morid fish of the Rockall Trough. J. Mar. Biol. Ass. U.K., 64: 657-665.

1984b. Diets and bathymetric distributions of the macrourid fish of the Rockall Trough, northeastern Atlantic Ocean. Mar. Biol., 81: 107-121.

1984c. Occurrence and feeding of berycomorphid and percomorphid teleost fish in the Rockall Trough. ICES J. Cons., 41: 239-247.

1984d. Occurrence of stones sediment and fish scales in stomach contents of demersal fish of the Rockall Trough. J. Fish Biol., 24: 357-362.

$1984 \mathrm{e}$. Incidence of parasitic worms in stomachs of pelagic and demersal fish of the Rockall Trough, northeastern Atlantic Ocean. J. Fish Biol., 24: 281-285.

1985. Trophic diversity in deep-sea fish. J. Fish Biol., 26: 527-535.

1986. Foraging strategies of deep-sea fish. Mar. Ecol. Prog. Ser., 27: 227-238.

1991. Oceanic pelagic prey of benthopelagic fish in the benthic boundary layer of a marginal oceanic region. Mar.Ecol. Prog. Ser., 74: 109-115.

MAUChline, J., D.J., ELlETT, J.D. GAGE, J. D. M. GORDON, and E. J. W. JONES. 1986. A bibliography of the Rockall Trough. Proc. R. Soc. Edinb., 88: 319-354.

McDIARMID, H. MS 1974a. Exploratory Voyage by D.E T. Swanella. White Fish Authority Technical Report, No. 101, 31p.

MS 1974b. Deep water fishing voyage on MT Luneda, White Fish Authority Technical Report, No. 108,8 p.+ figures and tables.

MERRETT, N. R., and WHEELER, A. 1983. The correct identification of two trachichthyid fishes (Pisces, Berycomorphi) from the slope fauna west of Britain, with notes on the abundance and commercial importance of Hoplostethus atlanticus. J. Nat. Hist., 17: 569-573.

MERRETT, N. R., J. BADCOCK, S. EHRICH, and P. A. HULLEY. 1986. Preliminary observations on the nearbottom ichthyofauna of the Rockall Trough: a contemporaneous investigation using commercial-sized mid-water and demersal trawls to $100 \mathrm{~m}$ depth. Proc. $R$. Soc. Edinb., 88B: 312-314.

MERRETT, N. R., J. D. M. GORDON, M. STEHMANN, and R. L. HAEDRICH. 1991a. Deep demersal fish assemblage structure in the Porcupine Seabight (eastern North Atlantic): Slope sampling by three different trawls compared. J. Mar. Biol. Ass. U.K., 71: 329-358.

MERRETT, N.R., R. L. HAEDRICH, J. D. M. GORDON, and M. STEHMANN. 1991b. Deep demersal fish assemblage structure in the Porcupine Seabight (eastern North Atlantic): Results of single warp trawling at lower slope to abyssal soundings. J. Mar. Biol. Ass. U.K., 71: 359-373.

MitCHELL, L, S. M., HARVEY, J. D. GAGE, and A. E. FALLICK. 1997. Organic carbon dynamics in shelf edge sediments off the Hebrides: a seasonal perspective. Int. Rev. Gesamten. Hydrobiol., 82: 425-435.

MORALES-NIN, B., and D. SENA-CARVALHO. 1995. Age and growth of the black scabbard fish (Aphanopus carbo) off Madeira. Fish. Res., 25: 239-251.

MORALES-NIN, B., Â. CANHA, M. CASAS, I. FIGUEREIDO, L. S. GORDO, J. D. M. GORDON, E. GOUVEIA, C. G. PIÑEIRO, S. REIS, A. REIS, and S. C. SWAN. 2002. Intercalibration of age readings of deep-water black scabbard fish Aphanopus carbo (Lowe, 1839). ICES J. Mar. Sci., 59: 352-364.

MORDUE, W. (ed.). 2001. The marine environment of the North East Atlantic Margin. Cont. Shelf Res., 21, 7651120.

MORMEDE, S., and I. M. DAVIES. MS 1998. Trace elements in deep-water fish species from the Rockall Trough. ICES C.M. Doc., No. O:55, 15 p.

2000. Polychlorobiphenyl and pesticide residues in monkfish and black scabbard from the Rockall Trough. ICES Coop. Res. Rep., 240: 19-20.

2001a. Trace elements in deep-water fish species from the Rockall Trough. Fish. Res., 51: 197-206.

2001 b. Heavy metal concentrations in commercial deep-sea fish from the Rockall Trough. Cont. Shelf Res., 21: 899-916.

2001c. Poly-chloro-biphenyl and pesticide residues in monkfish Lophius piscatorius and black scabbard Aphanopus carbo from the Rockall Trough. ICES J. Mar. Sci., 58: 725-736.

MURRAY, J. 1886. The physical and biological conditions of the seas and estuaries about North Britain. Proc. Phil. Soc. Glasg., 17: 306-333.

MURRAY, J., and J. HJORT. 1912. The depths of the ocean. A general account of the modern science of oceanography based largely on the scientific researches of the Norwegian steamer Michael Sars in the North Atlantic. 
Macmillan and Co., London, $821 \mathrm{p}$.

OLSEN, H. E. 1995. Norwegian experience of deep-water fishing with longlines. In: Deep-water Fisheries of the North Atlantic Oceanic Slope. A. G. Hopper (ed.), Netherlands, Kluwer Academic Press, p. 367-373.

PASCOE, P. L. 1990. Light and the capture of marine animals. In: Light and life in the sea. P. J. Herring, P. J. Campbell, A. K. Whitfield and L. Maddock (eds.), Cambridge University Press, p. 229-244.

PECHENIK, L. N., and F. M. TROYANOVSKY. 1970. Trawling resources on the North Atlantic continental slope. Israel Program for Scientific Translations, 1971, Cat. No. 5977, 66 p.

POPE, J., and D. SYMES. 2000. An ecosystem based approach to the common fisheries policy: defining the goals. Published by English Nature, Peterborough, U.K., $40 \mathrm{p}$.

RÄTZ, H.J. 1984. Qualitative und quantitative Untersuchungen der Ichthyozoenose in der archibenthischen Zone des Rockall-Grabens und umleigender Banke (Westbritische Gewasser). Mitt. Inst. Seefisch., No. 34, 152 p.

REINERT, J. 1995. Deep-water resources in Faroese waters to the south, southwest and west of the Faroes. A preliminary account. In: Deep-water fisheries of the North Atlantic Oceanic slope. A. G. Hopper (ed.), Kluwer Academic Publishers, The Netherlands, p. 201-225.

RICE, A. L. 1986. British Oceanographic vessels 1800 to 1950. The Ray Society, London, 193 p.

RICE, A. L., D. S. M. BILLETT, M. H. THURSTON, and R. S. LAMPITT. 1991. The Institute of Oceanographic Sciences Biology Programme in the Porcupine Seabight: background and general introduction. J. Mar. Biol. Ass. U.K., 71: 281-310.

ROBERTS, J. M., S. M. HARVEY, P. A. LAMONT, J. D. GAGE, and J. D. HUMPHERY. 2000. Seabed photography, environmental assessment and evidence of deepwater trawling on the continental margin west of the Hebrides. Hydrobiol., 441: 173-183.

ROGERS, A. D. 1999. The biology of Lophelia pertusa (Linnaeus 1758) and other deep-water reef-forming corals and impacts from human activities. Int. Rev. Hydrobiol., 84: 315-406.

SANTOS, A. M. P. (ed.). 2000. Environment and biology of deep-water species, Aphanopus carbo (Lowe, 1839) in NE Atlantic: basis for its management (BASBLACK). Final Consolidated Report of EC DGXIV Study Contract 97/0084, $94 \mathrm{p}$.

SCHARFF, R. F. 1890. Report of the fishes obtained off the south coast of Ireland during the cruises of the "Lord Bandon" and the "Flying Falcon" 1886 and 1888. Proc. Roy. Irish Acad., 1 (3 ${ }^{\text {rd }}$ Series): 456-459.

SCRUTTON, R. A. 1986. The geology, crustal structure and evolution of the Rockall Trough and the Faeroe-Shetland Channel. Proc. R. Soc. Edinb., 88B: 7-26.

STENE, A., and A. BUNER. MS 1991. Forsøksfiske med liner vest for Shetland, Færøyene og Hebridene, Samt På Reykjanesryggen. Møreforsking Alesund (Unpubl. Report), $60 \mathrm{p}$.
SWAN, S. C., and J. D. M. GORDON. 2001. A review of age estimation in macrourid fishes with new data on age validation of juveniles. Fish. Res., 51: 177-195.

THIEL, H. and J. A. KOSLOW (eds.). 2001. Managing risks to biodiversity and environment on the high sea, including tools such as marine protected areas - scientific requirements and legal aspects-. Proceedings of the expert workshop held at the International Academy for Nature Conservation, Isle of Vilm, Germany, 27 February4 March. BfN-Skripten, 43, Bonn Germany, 216 p.

THOMAS, R. 1987. Biological investigations on the blue ling, Molva dypterygia dypterygia (Pennant 1784 after O. F. Mueller 1776), in the areas of the Faroe Islands and to the West of the Shetland Islands. Arch. Fischereiwiss., 38: 9-34.

THOMSON, C. W. 1873. The Depths of the Sea. London, Macmillan and Co., 527 p.

THOMSEN, B. MS 1998. Faroese quest of orange roughy in the North Atlantic. ICES C.M. Doc., O:31, 8 p.

MS 1999. Faroese deep-sea fisheries in the Northeast Atlantic. Unpublished Manuscript presented to the "Open Hearing on Deep Sea Species", European Commission 22 June 1999, 6 p.

TRACEY, D. M., and P. L. HORN. 1999. Background and review of ageing orange roughy (Hoplostethus atlanticus, Trachichthyidae) from New Zealand and elsewhere. N.Z. J. Mar. Freshw. Res., 33: 67-86.

VAS, P. 1991. Trace metal levels in sharks from British and Atlantic waters. Mar. Pollut. Bull., 22: 67-72.

VAS, P., and J. D. M. GORDON. 1988. Trace metal concentrations in the scyliorhinid shark Galeus melastomus from the Rockall Trough. Mar. Pollut. Bull., 19: 396-398.

1993. Trace metals in deep-sea sharks from the Rockall Trough. Mar. Pollut. Bull., 26: 400-402.

VAS, P., J. D. M. GORDON, P. R. FIELDEN, and J. OVERNELL. 1993. The trace metal ecology of ichthyofauna in the Rockall Trough, north-eastern Atlantic. Mar. Pollut. Bull., 26: 607-612.

VINNICHENKO, V. I. MS 2000. Historical review of the Soviet Deepwater investigation and fishery in the open northeast Atlantic (The Outer-Bailey Bank, Hatton Plateau, Rockall Rising). Working Document for ICES Study Group on the Biology and Assessment of Deepsea Fishery Resources, 2000.

VINNICHENKO, V. I., and V. N. KHLIVNOY. MS 2001. Russian deep-sea investigations and fisheries in the northeast Atlantic in 2000. Working Document for ICES Working Group on the Biology and Assessment of Deepsea Fishery Resources, 2001.

WENT, A. E. J. 1971/72a. Four late nineteenth-century expeditions organised by the Royal Irish Academy. Proc. R. Soc. Edinb., 72B: 305-309.

1971/72b. The role of the Royal Dublin Society (established in 1731) in fisheries research and development. Proc. R. Soc. Edinb., 73B: 345-350.

WILSON, C. D., and M. P. SEKI. 1994. Biology and population characteristics of Squalus mitsukurii from a 
seamount in the central North Pacific Ocean. Fish. Bull. U.S., 92 : 851-864.

WOOD, R. J., and D. F. S. RAITT. 1968. Some observations on the biology of the greater silver smelt particularly in the north-eastern Atlantic Ocean. ICES Rapp. Proc.Verb., 158: 64-73. 